\title{
Plus ça change: pots, crucibles and the development of metallurgy in Chalcolithic Las Pilas (Mojácar, Spain)
}

\author{
Miguel del Pino Curbelo ${ }^{1}$ (D) Peter M. Day ${ }^{1} \cdot$ María Dolores Camalich Massieu ${ }^{2} \cdot$ Dimas Martín Socas $^{2}$. \\ Fernando Molina González ${ }^{3}$
}

Received: 2 October 2017 / Accepted: 6 March 2018 / Published online: 27 March 2018

(C) The Author(s) 2018

\begin{abstract}
This paper considers the structure of production, distribution and consumption of ceramics within Chalcolithic communities of SE Iberia, an important region for modelling social and technological change in the recent prehistory of Eurasia. Our research provides new data through the comparative analysis of domestic and metallurgical ceramics, as well as building and other clay-

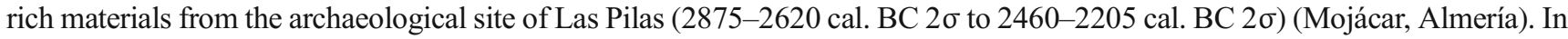
total, 56 samples are characterised by optical petrography, with SEM analysis of 22 of those individuals, in order to assess firing conditions. Results point to the existence of a local tradition in which domestic and metallurgical wares exhibit important similarities in their production processes. In terms of technology, the assemblage shows a relative homogeneity, although firing conditions, surface treatment and decoration seem to have played an important role in the differentiation of highly symbolic wares from other ceramics. We conclude that raw material procurement and processing at Las Pilas differ from those at other Copper Age sites already studied in SE and SW Iberia. This is in agreement with earlier archaeometallurgical studies on Las Pilas, suggesting the development of local and community-based technological traditions. As such, the paper attempts to bridge the recent divide between re-emergent top-down models and our detailed understandings of technological practice.
\end{abstract}

Keywords SE Iberia $\cdot$ Chalcolithic $\cdot$ Ceramic petrography $\cdot$ SEM

Miguel del Pino Curbelo

m.delpino@sheffield.ac.uk

Peter M. Day

p.m.day@sheffield.ac.uk

María Dolores Camalich Massieu

dmassieu@ull.edu.es

Dimas Martín Socas

dsocas@ull.edu.es

Fernando Molina González

molinag@ugr.es

1 Department of Archaeology, University of Sheffield, Minalloy House, 10-16, Regent Street, Sheffield S1 3NJ, UK

2 Departamento de Prehistoria, Arqueología, Antropología e Historia Antigua, Universidad de La Laguna, Campus de Guajara, 38205 La Laguna, Spain

3 Departamento de Prehistoria y Arqueología, Universidad de Granada, Campus Universitario de Cartuja, 18071 Granada, Spain

\section{Introduction}

The Chalcolithic in south-eastern Iberia (3200-2200 BC) has been characterised as a period of change during which local populations took their first steps towards social complexity. The area has been crucial in the construction of models of social change (Ramos Millán 1981; Lull 1983; Mathers 1984; Chapman 1990; Díaz-Andreu 1995) and especially of the spread of metalworking in the Old World (Renfrew 1967; Montero Ruiz and Murillo-Barroso 2014; Roberts 2008, 2014). Despite intensive research undertaken in the area, key questions remain open, concerning the structure of production, distribution and consumption of goods, as well as the actual role played by craft in social change. In essence, there is a need for a better understanding of the practice not only of metallurgy, but also its interface with ceramic and other clay products, of understanding the relationship between everyday practice and the models of the transmission of specific technologies. In attempting to bridge the recent divide between reemergent top-down models and our detailed understandings of practice, this paper presents new data precedent from the 
analysis of a variety of clay-based remains (domestic pottery, metallurgical ceramics and building materials) from the archaeological site of Las Pilas (Mojácar, Almería).

\section{Metals and social change in SE Iberia}

Marked changes in architecture and material culture during the Chalcolithic have been taken as indicators of emergent social complexity and the appearance of metallurgy in southern Iberia, which were materialised in a number of different ways at a regional scale (Leisner and Leisner 1943). In this context, the territory that nowadays forms the province of Almería (SE Spain), and especially the site of Los Millares, has been a particular focus of research. Within this area, intensive research in the Vera Basin (Fig. 1), notably during the 1980s-1990s, has brought a wealth of information regarding social and technological change from the Neolithic to the Bronze Ages (e.g. Chapman 1990; Fernández-Miranda et al. 1993; Montero Ruiz 1993; Delibes et al. 1996; Ruiz-Taboada and Montero-Ruiz 1999a, 1999b; Camalich Massieu and Martín Socas 1999; Risch et al. 2002).

The results of this work have been much discussed; indeed, the degree of complexity present in local communities, the motivations for social change and how this change is reflected in labour organisation have all been matters of controversy. In general, explanatory models for emergent social complexity in the Chalcolithic range from those who argue for a high degree of specialisation and social ranking (influenced by the interpretation of Los Millares, Molina et al. 2004) to others that maintain that household production and a lower degree of social differentiation were dominant (Lull et al. 2010; Chapman 2008; Montero Ruiz and Murillo-Barroso 2016). The usual issues that have formed the basis for such models and debates have been the control of water, agrarian surplus and the nature and extent of exchange networks.

Recently, however, attention has turned to complex models which emphasise the origins of metallurgical practice and the role of technology in the organisation of production (Nocete et al. 2008; Roberts 2014). As in many other regions, the explanatory models for this phenomenon in SE Iberia range from diffusion to local development, in both cases with deep implications for our understanding of the way that metallurgy affected local social relations. In the former case, the arrival of metallurgy is seen to encourage specialisation, due to the need to mobilise communities and secretiveness around metalworking (Roberts 2008), while the supporters of local development suggest that the process of differentiation and social ranking was already in train before metal consumption became a powerful social factor (Montero Ruiz and MurilloBarroso 2016).

\section{Recent prehistory in the region of study}

The first evidence for human colonisation of the Vera Basin dates back to the Early Neolithic (approx. 5400-4900 cal. BC, Martín-Socas et al. 2017). This early occupation is represented by small settlements made up of perishable structures, probably related to either seasonal or periodic occupation and located close to fresh water and marine resources, such as at Cerro Virtud (Ruiz-Taboada and Montero-Ruiz 1999a, b) and

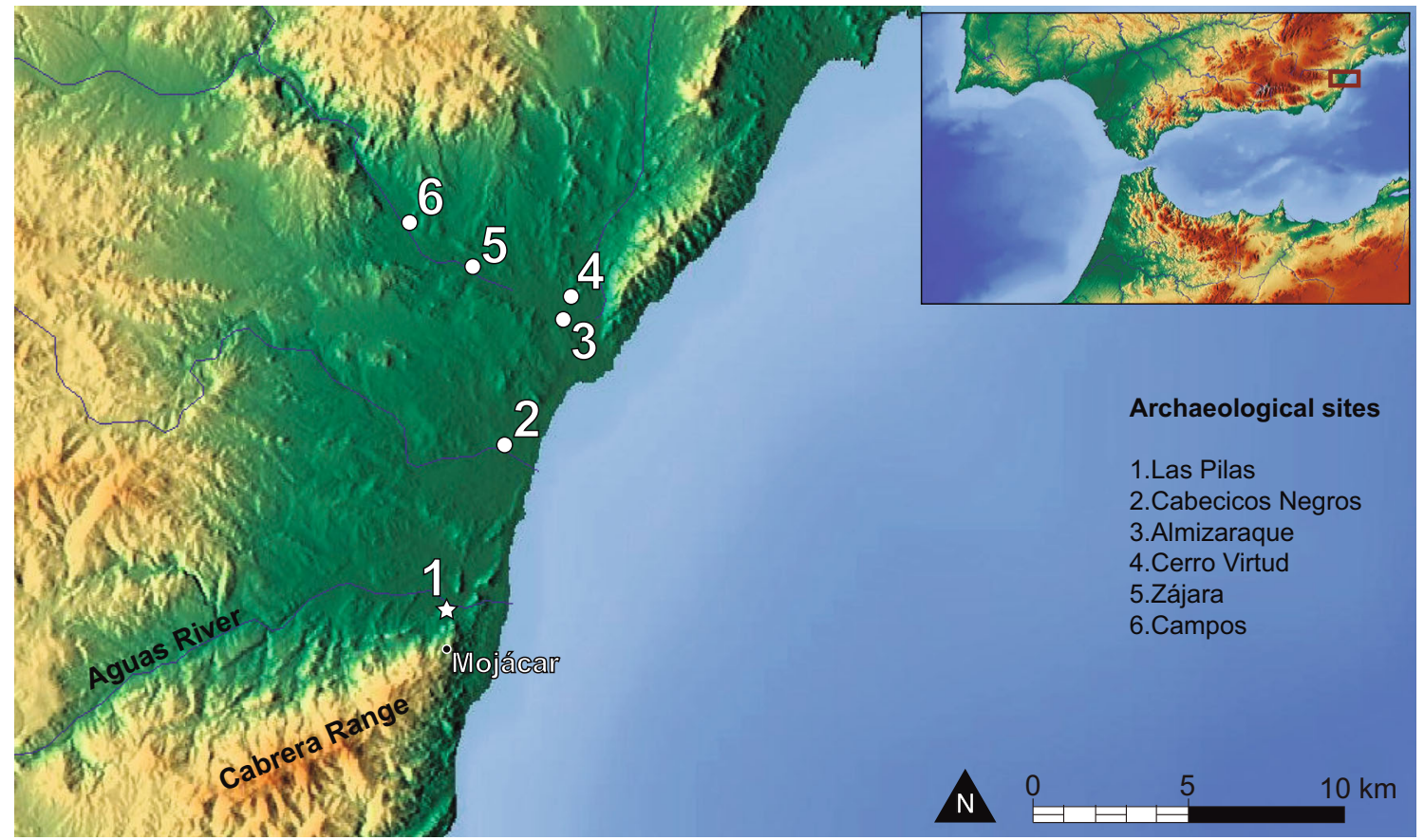

Fig. 1 Location of the main archaeological sites referred to in the text 
Cabecicos Negros (Camalich et al. 1999). A number of these settlements increased by the end of the Neolithic when they were also inhabited for longer periods of time, as evidenced by the construction of negative structures and the introduction of megalithic monuments into SE Iberia (Aranda Jiménez et al. 2017).

It is during the Chalcolithic, in the third millennium $\mathrm{BC}$, that major change took place, as the result of demographic growth and an increase in socioeconomic complexity. By this time, a number of stable, enclosed hamlets became keystones in the control of communication pathways and natural resources (Camalich et al. 1999), along with unenclosed smaller settlements and characteristic megalithic tombs that hosted a range of individuals and grave goods (Aranda Jiménez et al. 2017).

Chalcolithic open-air settlements comprised a variable number of circular huts with stone foundations and timber structures, which were the scene of everyday activities (Chapman 2008; Lull et al. 2010). The effort invested in building durable domestic constructions, along with walls and a number of dug structures, possibly employed as silos, water storage pits and ditches, is equally taken as a sign of an increase of population and a higher degree of sedentism (Chapman 2008 and references therein). Nevertheless, the internal organisation of such domestic contexts is poorly understood, with production contexts clear in some cases, such as Los Millares (Molina and Cámara 2005), but not apparent on other sites (Delibes et al. 1989; Lull et al. 2010).

As in other European settings (Doonan et al. 2007; Dolfini 2013; Roberts 2014; Perucchetti et al. 2015; Radivojević and Rehren 2016), how and when metalworking was developed in SE Iberia has become central to understanding the role of technology in social change, as well as processes of invention and diffusion. In these terms, researchers' attention has been drawn to the peculiarities exhibited by the metallurgical tradition developed in SE Iberia and its contrasts with neighbouring areas. Its earliest metalworking has been defined as a low-intensity activity, focused on tools and weapons, characterised by low slag production under conditions of incomplete reduction and by the absence of common signs of annealing until the second millennium BC (Montero Ruiz 1993; Müller et al. 2006; Rovira and Renzi 2017). The relative balance in the amount of copper goods recovered from domestic as opposed to funerary contexts may suggest that copper production and consumption was part of a regional system of values in which metal did not acquire a central role in the expression of power relations until the Late Chalcolithic (Murillo-Barroso and Montero-Ruiz 2012).

If this was the case, traditional technologies continued to be fundamental in the production and reproduction of those material conditions that, in turn, sustained social, economic and political structures and their subsequent change. A good example of this is the exchange and use of new and exotic materials, such as amber, ivory, ostrich eggshells or a variety of rocks and minerals, central to the flourishing industry of personal adornment (i.e. Harrison and Gilman 1977; Hunt-Ortiz et al. 2011; Murillo-Barroso and Martinón-Torres 2012). While these goods were central to promoting social asymmetry, they were also entangled with a wide range of common goods made out of clay, stone, animal bones and vegetal materials, the very basis of most day-to-day activities. Of course, these traditional industries were also involved in metalworking, either through the phenomenon of skeuomorphism, through accumulated knowledge of pyrotechnology or by being active in ore extraction and processing (Rovira 2005; Risch 2008; Rovira and Renzi 2017).

\section{Ceramics in the Chalcolithic of SE Iberia}

Ceramics were an active component in everyday life before the arrival of metals and also a key component in early metallurgical practice. For that reason, here, we concentrate on ceramic technology, placing it in relation to other clay-rich resources. Chalcolithic ceramics form a number of welldefined functional groups (cooking pots, storage jars, prestige vessels) and exhibit a wide range of technological solutions that often involve the combination of different raw materials and the use of a range of forming techniques, e.g. moulding, coiling and pinching (Camalich Massieu and Martín Socas 1999; Inácio et al. 2013) (Fig. 2).

The most characteristic ceramic types of this period are open and shallow vessels, known as trays (fuentes), plates (platos) and bowls (cuencos); none of which exhibit decoration (Camalich Massieu and Martín Socas 1999). These have been connected to food processing and consumption. Also characteristic of SE Iberia is the relatively high incidence of symbolic (cerámica simbólica) and orange wares (cerámica de pasta naranja), which have fine, compact fabrics; careful surface treatment; and a relatively homogenous colour, due to well-controlled firing conditions. These occur in far smaller numbers than the domestic wares mentioned above and are therefore considered to be prestige goods.

There are some specific typological and technological traits typical of the Chalcolithic, such as the presence of linear protuberances on the exterior body (baquetones), low-carinated profiles, painted decoration and thickened and everted rims. Most of these traits are present since the Late Neolithic (Gavilán Ceballos 1997), as are the elements of schematic decoration observed in symbolic ware (Martín Socas and Camalich Massieu 1982; Pellicer Catalán 1995). In fact, some ceramic types characteristic of the Late Neolithic in the area, such as the Almeria type, seem to be still in use during the Chalcolithic, as observed in Campos and Zájara (Camalich Massieu and Martín Socas 1999).

Beyond ceramics, clay-rich materials were employed in the construction of a number of structures, such as huts and fireplaces and as a waterproof lining for pits within the 

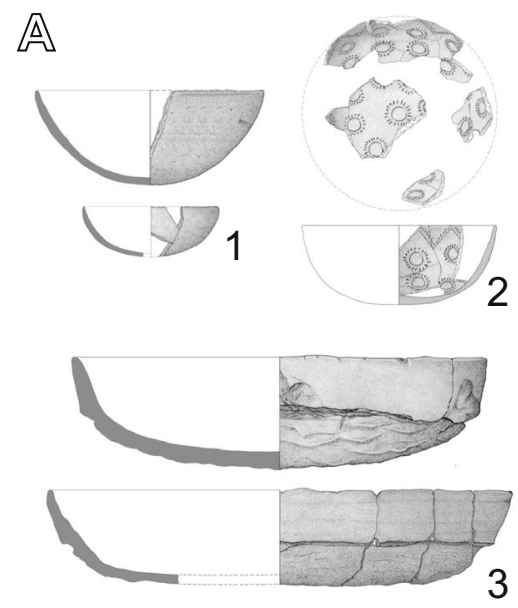

Fig. 2 a Representative reconstructed pottery of Chalcolithic ceramic types from the Vera Basin. All drawings are on the same scale: 1 cuencos (bowls), 2 cerámica simbólica (symbolic ware) with schematic decoration, 3 fuentes (trays) exhibiting traces of moulding, 4 recipiente de

settlements (Delibes et al. 1996; Chapman 2008). These other uses can shed light on the knowledge and choices of the community in terms of raw material exploitation and available local resources.

Of course, a key feature of this period is the use of ceramics in ore processing and metalworking, in the form of crucibles, blowpipe nozzles and, perhaps, other objects (for a detailed discussion, see Rovira and Ambert 2002). The analysis of these technical implements and their comparison with domestic wares helps assess any relationship between their production processes and those used in making domestic pottery. Due to the extreme conditions in which crucibles are used, it might be expected that specific strategies were developed to combat thermal shock that metallurgical ceramics underwent. Correspondences between raw material choices for ceramic fabrics made to perform different domestic functions have been noted in other sites of southern Iberia (Camalich Massieu and Martín Socas 1999; Molina and Cámara 2005; Inácio et al. 2012). Nevertheless, such information is scarce and, at times, unclear, with no convincing differences detailed when metallurgical and domestic ceramics have been compared in depth (Murillo-Barroso et al. 2017). If we accept metalworking as a highly symbolic activity (Childe 1930; Eliade 1978; Budd and Taylor 1995), conceived of as concealed knowledge, surely that should have affected how metallurgical ceramics were produced, perhaps making them stand out in contrast to the way that domestic pottery was used and had been used previously.

\section{Ceramics and the arrival of metallurgy}

Improving our knowledge of the manufacture and consumption of the wide range of clay-rich goods offers us the potential to contextualise the material conditions of and changes in
回
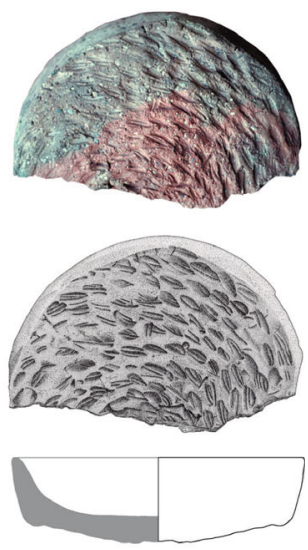

$5 \mathrm{~cm}$

almacenamiento (storage jar) with baquetón (linear protuberance). b A plate (plato) with signs of the use of a vegetal mould to build the vessel. Scale differs from the previous examples (after Camalich Massieu and Martín Socas 1999)

Chalcolithic economic and social structures. Given the importance of technology in the definition of regional differences in the development of social complexity and metallurgy, ceramic analysis comprises an important tool in shedding light on innovation and the transmission of knowledge and, through them, on social relations and technological change (Dobres 2010).

The main objective of this paper is to contribute new data on the Chalcolithic in SE Iberia through ceramic analysis. A local perspective is deliberately adopted, as studies of technological and social practice at this scale are necessary in order to construct robust models at a larger scale. This also allows the integration of other empirical data produced in the last decades. The project:

1. Explores the strategies of raw material procurement and processing adopted by the inhabitants of a Chalcolithic settlement in SE Iberia.

2. Defines the relations between the production processes developed and the function of clay-rich products, particularly focused on the most common ceramic groups present on the record.

3. Discusses the resulting data with regard to the main explanatory models for the Chalcolithic in SE Iberia concerning labour specialisation and technological innovation.

\section{The archaeological site of Las Pilas}

\section{Archaeological background}

The materials analysed in this paper derive from the archaeological site of Las Pilas, in Almería (Spain), located on a flat elevation close to the Aguas River, ca. $30 \mathrm{~m}$ above the sea level, north from the city of Mojácar. The site has been the 
object of three different archaeological campaigns (Alcaraz Hernández 1992; Camalich Massieu and Martín Socas 1999; Murillo-Barroso et al. 2017). Those excavations unearthed an extensive (ca. 5 ha), enclosed hamlet occupied during the third millennium BC, and its stratigraphy has indicated ten phases of occupation.

Although scarce, the first evidence of metalworking at the site date to the beginning of the third millennium BC (Beta-408051,

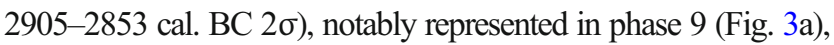
chronologically spanning from 2570-2460 cal. BC $2 \sigma$ (Beta$408061)$ to $2460-2205$ cal. BC $2 \sigma$ (Beta-408065). Then, an activity area devoted to food processing (cereal roasting) and copper smelting was bounded by a circular or oval wall surrounded by a 30-cm-wide ditch and was structured around two hearths (Fig. 3b). One of them occupied a central position within this area and was involved in the processing of staples. The second was located at the edge and delimited by adobe bricks. A complete set of metalworking appliances was recovered in connection with this second structure, including crucibles and blowpipe nozzles (Fig. 3c, d).

This activity area dates to the period of consolidation and spread of social asymmetry and metallurgy in SE Iberia. Contemporaneous remains of metalworking in the rectangular building of Los Millares have been considered a sign of change in the status of metalworking in the site (Molina and Cámara 2005; Lull et al. 2010). For this reason, on the basis of the archaeological materials available, a comparative analysis of metallurgical and domestic ceramics was undertaken, along with a raw clay-rich lump and some building materials (Table 1, F1-F7 for fabrics 1-7).

In order to approach questions related to knowledge transmission and diachronic change, samples of domestic wares and building materials from the previous occupation phase 8

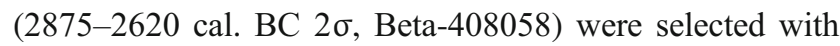
comparative proposes (Table 1).

\section{Geological environment}

The site of Las Pilas is located in the foothills of the Cabrera range, the southern limit of the Vera Basin, about $2 \mathrm{~km}$ from the coast and only a few meters from the course of the Aguas River (Fig. 4). According to geological mapping (Espinosa Godoy et al. 1974a, 1974b; Kampschuur and García Monzón 1975; Kampschuur et al. 1975), the main orogenic units in the area are formed by the Alpujárride complex, the result of Eocene to Early Miocene Alpine activity. The oldest materials (Precambrian-Devonian) of this complex are only located to the $\mathrm{E}$ and $\mathrm{S}$ of the Cabrera range, comprising

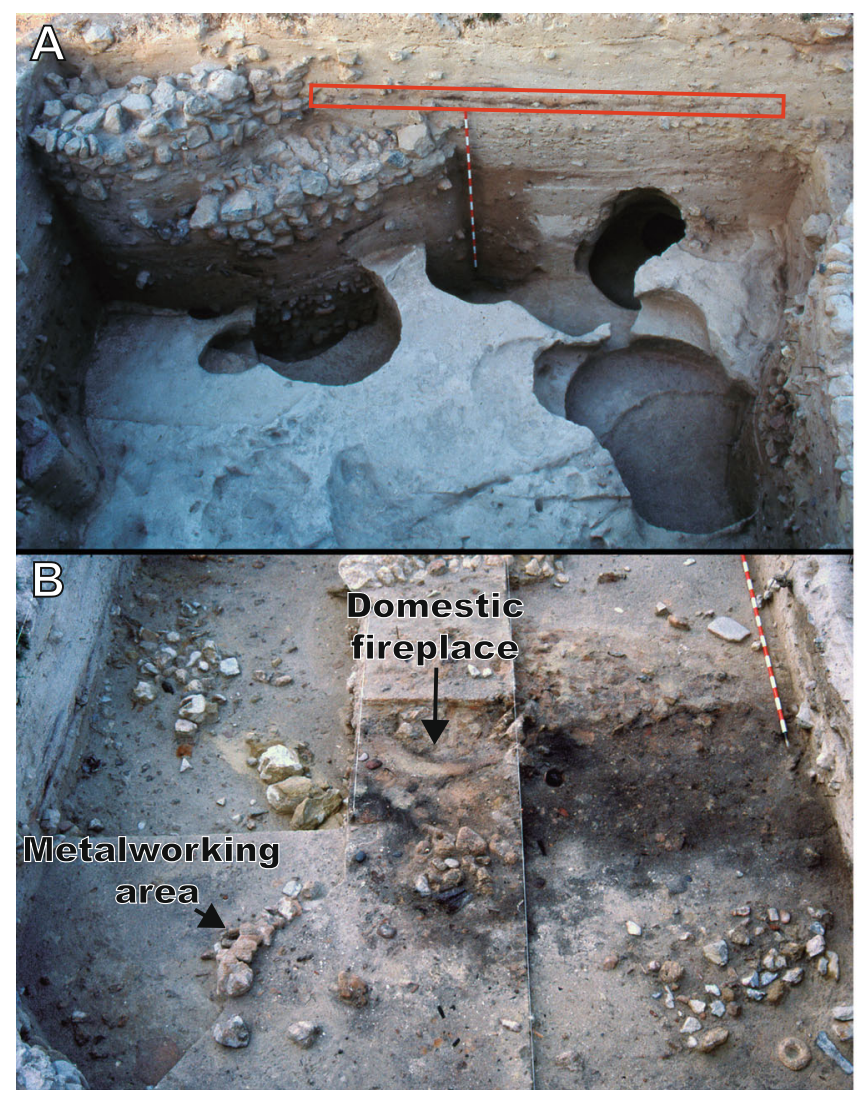

C

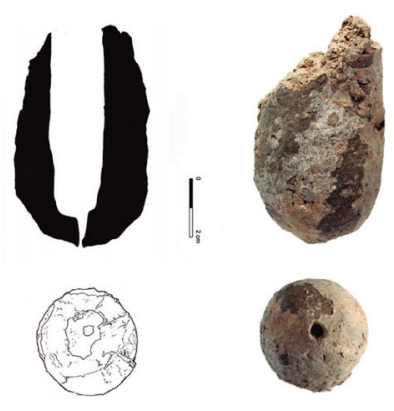

$5-7250$

$\underline{2 \mathrm{~cm}}$

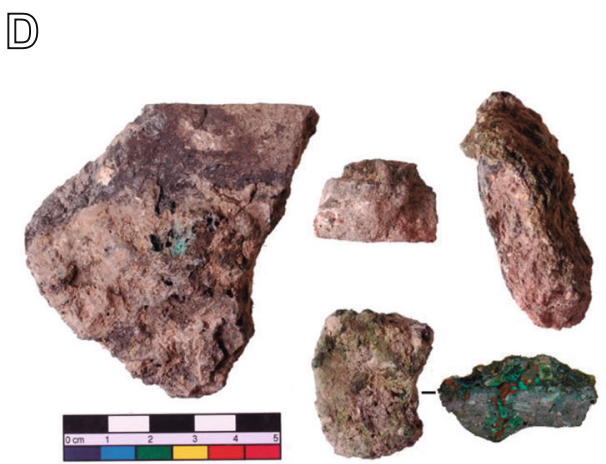

Fig. 3 a General view of the archaeostratigraphic series of the site. Phase 9 is indicated with a rectangle. b Archaeological levels associated to ceramics recovered on the site (after Murillo-Barroso et al. 2017). c Blowpipe nozzle. d Crucible fragments 
Table 1 Samples analysed and summary of results

\begin{tabular}{|c|c|c|c|c|c|c|c|}
\hline Fabric & Lab reference & Sample & Phase & Macroscopic classification & SEM & Relict coil & Fast Firing \\
\hline $\mathrm{F} 1$ & MPL-007 & $5-6685-4$ & 9 & $\mathrm{~b} / \mathrm{s}$ & & & \\
\hline $\mathrm{F} 1$ & MPL-017 & $5-6658-6$ & 9 & $\mathrm{~b} / \mathrm{s}$ & & & \\
\hline $\mathrm{F} 1$ & MPL-025 & $5-5346$ & 9 & $\mathrm{~b} / \mathrm{s}$ & & & \\
\hline $\mathrm{F} 2$ & MPL-022 & $5-5356$ & 9 & $\mathrm{~b} / \mathrm{s}$ & & & \\
\hline F3 & MPL-004 & $5-5405-1$ & 9 & $\mathrm{~b} / \mathrm{s}$ bevelled rim & NV & & \\
\hline F3 & MPL-012 & $5-6804-21$ & 8 & Cooking pot & IV & & \\
\hline F3 & MPL-018 & $5-6685-3$ & 8 & $\mathrm{~b} / \mathrm{s}$ & & & \\
\hline F3 & MPL-101 & $5-5720-36$ & 9 & $\mathrm{~b} / \mathrm{s}$ bevelled rim & $\mathrm{V}$ & & $\mathrm{x}$ \\
\hline F3 & MPL-102 & $5-5721$ & 9 & $\mathrm{~b} / \mathrm{s}$ moulding & & & \\
\hline F3 & MPL-108 & $5-7394-2$ & 8 & Cooking pot & IV & $\mathrm{x}$ & \\
\hline F3 & MPL-109 & $5-7427-12$ & 9 & Crucible & & & \\
\hline F3 & MPL-112 & $5-7518-36$ & 9 & Crucible & & & \\
\hline $\mathrm{F} 3$ & MPL-113 & $5-7582-14$ & 9 & Crucible & & & \\
\hline $\mathrm{F} 4$ & MPL-011 & $5-6658-31$ & 8 & Carinated vessel & IV & & \\
\hline F5 & MPL-006 & $5-6697-2$ & 8 & $\mathrm{~b} / \mathrm{s}$ & IV & & \\
\hline F5 & MPL-008 & $5-6685-2$ & 8 & $\mathrm{~b} / \mathrm{s}$ & & & \\
\hline F5 & MPL-010 & $5-5342-2$ & 9 & $\mathrm{~b} / \mathrm{s}$ thickened rim & NV & $\mathrm{x}$ & \\
\hline F5 & MPL-014 & $5-6685-5$ & 8 & Storage jar & IV & & \\
\hline F5 & MPL-020 & $5-6760-1$ & 9 & Bowl & IV & & \\
\hline F5 & MPL-105 & $5-6576-2$ & 8 & $\mathrm{~b} / \mathrm{s}$ thickened rim & & & \\
\hline F6 & MPL-001 & $5-6658-19$ & 9 & $\mathrm{~b} / \mathrm{s}$ & & & \\
\hline F6 & MPL-002 & $5-6685-1$ & 9 & $\mathrm{~b} / \mathrm{s}$ moulding & NV & & \\
\hline F6 & MPL-003 & $5-5358-2$ & 9 & Orange ware & NV & & \\
\hline F6 & MPL-005 & $5-6694$ & 8 & Almeria & & & \\
\hline F6 & MPL-009 & $5-7055-1$ & 9 & $\mathrm{~b} / \mathrm{s}$ & IV & & \\
\hline F6 & MPL-015 & $5-6702-11$ & 9 & Bowl & NV & & \\
\hline F6 & MPL-016 & $5-5336-4$ & 9 & $\mathrm{~b} / \mathrm{s}$ & & & \\
\hline F6 & MPL-019 & $5-7130-6$ & 9 & $\mathrm{~b} / \mathrm{s}$ moulding & IV & & $\mathrm{x}$ \\
\hline F6 & MPL-023 & $5-6628$ & 9 & $\mathrm{~b} / \mathrm{s}$ & & & \\
\hline F6 & MPL-024 & $5-6709$ & 9 & $\mathrm{~b} / \mathrm{s}$ & IV & & \\
\hline F6 & MPL-103 & $5-6020-3$ & 9 & $\mathrm{~b} / \mathrm{s}$ moulding & & $\mathrm{x}$ & \\
\hline F6 & MPL-104 & $5-6563$ & 8 & $\mathrm{~b} / \mathrm{s}$ moulding & NV & & \\
\hline F6 & MPL-106 & $5-7042$ & 8 & Bowl & & $\mathrm{x}$ & \\
\hline F6 & MPL-107 & $5-7385-2$ & 9 & Bowl & $\mathrm{V}$ & $\mathrm{x}$ & $\mathrm{x}$ \\
\hline F6 & MPL-110 & $5-7442-8$ & 9 & Crucible & & & \\
\hline F6 & MPL-111 & $5-7447-6$ & 9 & Crucible & & & \\
\hline F6 & MPL-13 & $5-5641-1$ & 9 & Crucible & & & \\
\hline F6 & MPL-M-01 & $5-6603$ & 9 & Crucible & & & \\
\hline F6 & MPL-M-02 & $5-6723$ & 9 & Crucible & & & \\
\hline F6 & MPL-M-03 & $5-6727$ & 9 & Crucible & & & \\
\hline F6 & MPL-M-04 & $5-6735$ & 9 & Crucible & & & \\
\hline F6 & MPL-M-05 & $5-6815$ & 9 & Crucible & & & \\
\hline F6 & MPL-M-06 & $5-6974$ & 9 & Nozzle & & & \\
\hline F6 & MPL-M-07 & $5-7317$ & 8 & Storage jar & IV & & $\mathrm{x}$ \\
\hline F6 & MPL-M-08 & $5-6966$ & 9 & Storage jar & NV & & \\
\hline F6 & MPL-M-09 & $5-6608$ & 8 & Symbolic ware & NV & & \\
\hline F6 & MPL-M-10 & $5-6616$ & 9 & Tray & & & \\
\hline F6 & MPL-M-11 & $5-6998$ & 9 & Tray & $\mathrm{V}$ & & \\
\hline F6 & MPL-M-12 & $5-7166$ & 9 & Raw/building mat & & & \\
\hline
\end{tabular}


Table 1 (continued)

\begin{tabular}{|c|c|c|c|c|c|c|c|}
\hline Fabric & Lab reference & Sample & Phase & Macroscopic classification & SEM & Relict coil & Fast Firing \\
\hline F6 & MPL-M-13 & $5-7417$ & 9 & Raw/building mat & & & \\
\hline F6 & MPL-M-14 & $5-7479$ & 8 & Raw/building mat & & & \\
\hline F6 & MPL-M-15 & $5-7250$ & 8 & Raw/building mat & & & \\
\hline F7 & MPL-021 & $5-7222$ & 9 & Symbolic ware & IV & & \\
\hline F7 & MPL-114 & $5-6781$ & 9 & Crucible & & & \\
\hline F7 & MPL-115 & $5-7116$ & 9 & Crucible & & & \\
\hline F7 & MPL-116 & $5-7252$ & 9 & Crucible & & & \\
\hline
\end{tabular}

$N V$ no vitrification, $I V$ initial vitrification, $V$ extensive vitrification

Palaeozoic graphitic mica schists, bearing white mica, quartz and Fe-rich opaque minerals, with marked variations in their accessory phases (mainly garnet- and epidote-bearing schists) and quartzite. Tectonically superimposed, there are Permianto-Triassic non-graphitic schists with biotite and epidote, and quartzite. Overlying this are deep formations of phyllite interspersed with quartzite. Finally, the highest strata are of Triassic carbonaceous material, comprising limestone containing albite, white mica, quartz and opaques.

The lowlands of the Vera Basin are covered by Tertiary marine and turbiditic deposits. Neogene levels at the southern limit of the basin are $200 \mathrm{~m}$ distant from the modern city of Mojácar. These deposits are formed by a series of marine sediments where the metamorphic materials are absent. They are mainly formed by marly globigerina-rich sediments, interspersed with layers of sandstone and conglomerate deposits. During the Quaternary, geological activity consisted mainly of
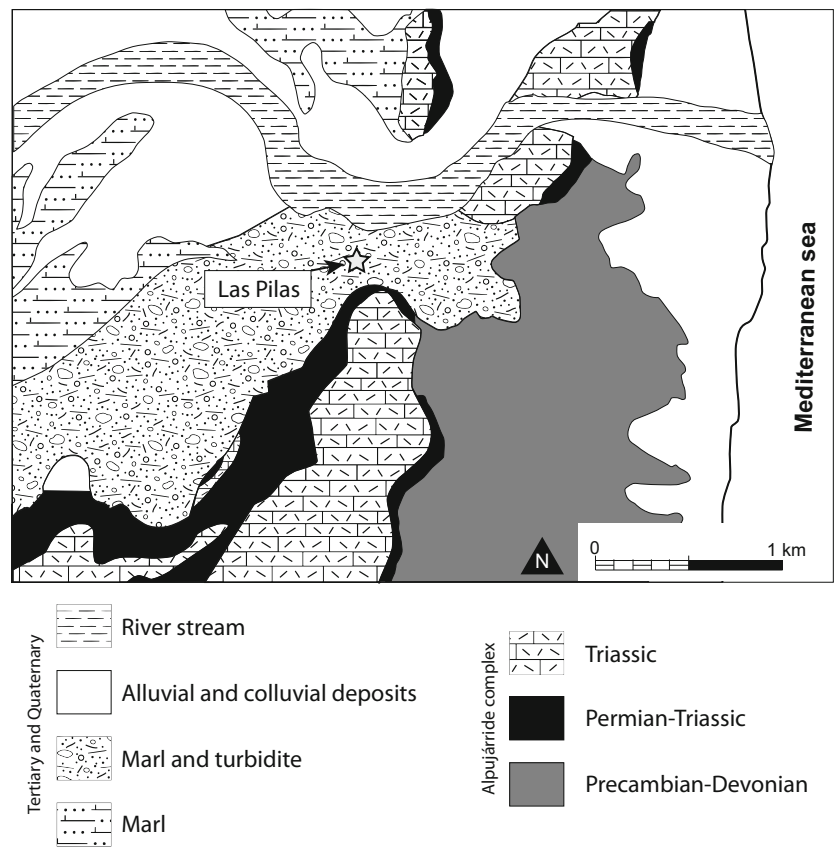

Fig. 4 Location of the site and geological map from the area under study (simplified from the IGME cartography, references in the text) alluviation along the Aguas River and the deposition of colluvium on the slopes of the mountains.

\section{Materials and methods}

All 56 samples come from the two pre-Bell Beaker phases of the site already described (phases 8 and 9). The samples represent the stylistic, technological and compositional variability observed macroscopically (Table 1) and encompass common ware (bowls, trays and plates; storage jars), cooking pots, prestige goods (symbolic and orange wares), technical ceramics (crucibles and blowpipe nozzles), building materials (clayey material from a hut, a furnace and a kiln) and a piece of unfired clayey material of unknown function. Some samples were selected to characterise variability both within and between macroscopic fabrics, where possible linking the material to known typological or functional groups.

Thin sections were prepared according to standard procedures and described using a modified version of the system proposed by Whitbread (1995, 2016). Following his proposal, the thin sections were grouped into petrographic fabrics according to their main components: aplastic inclusions, matrix and porosity. Grain size distribution and fabric components' orientation were estimated visually (Bullock et al. 1985), and the same approach was employed for the determination of frequency categories (Matthew et al. 1997). Moreover, the range of relative proportions of coarse and fine components, inclusive of voids, was calculated for each fabric (expressed as c:f:v), with the boundary between coarse and fine fractions set at $10 \mu \mathrm{m}$ (Whitbread 1995, p. 371). The indicative maximum grain size for each aplastic class is reported in fabric descriptions, in addition to the compositional and textural classification of the inclusions.

Representative individuals $(n=22)$ of each petrographic fabric were chosen for SEM examination on fresh fractures in order to observe the microstructure. This enabled an estimate of the degree of sintering and the vitrification state of the matrix, to undertake microanalysis of interesting features, e.g. Ca content. Bulk specimens were fixed on metal specimen stubs using silicone adhesive. Colloidal silver paint was applied on excess 
silicone adhesive and lateral sides of ceramic bulk specimen. The sample surface was coated with a thin carbon film ( $10 \mathrm{~nm}$ ) by vacuum evaporation. The instrument employed was a JEOL JSM-7100F thermal field emission scanning electron microscope (FESEM), coupled with the energy-dispersive X-ray spectroscopy (EDX) analyser INCA Penta FETx3 (Oxford Instruments) with Oxford Instruments INCA 4.11 software (The Microanalysis Suite Issue 18) with internal standards. The observations were performed using an acceleration voltage of $20 \mathrm{kV}$ and a working distance of $15 \mathrm{~mm}$.

\section{Results}

\section{Petrographic fabrics}

A total amount of seven petrographic fabrics (fabrics 17) were identified, six of which correspond to ceramics and one to samples from unfired clay-rich samples or building materials (Fig. 5). Two of the ceramic fabrics and that related to building materials are present in both phases.
Fig. 5 Micrographs showing meaningful compositional and textural traits of the petrographic fabrics in XP

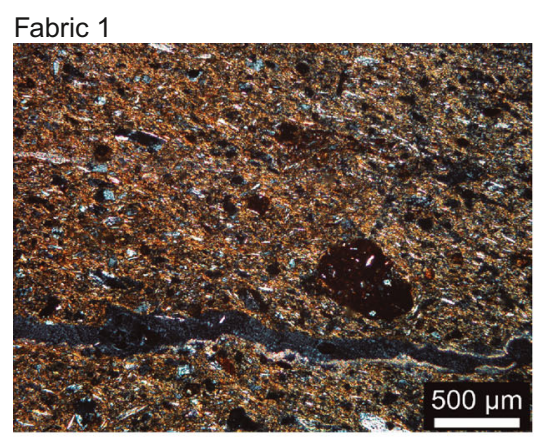

Fabric 3

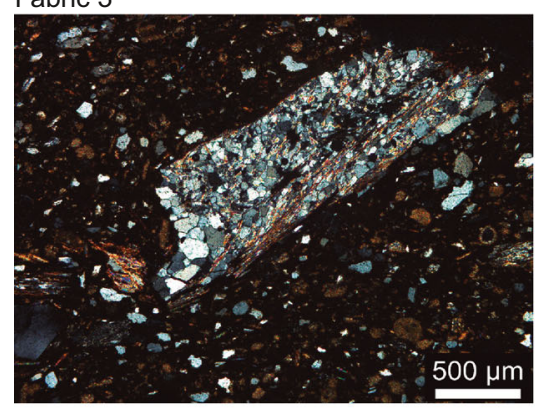

Fabric 5

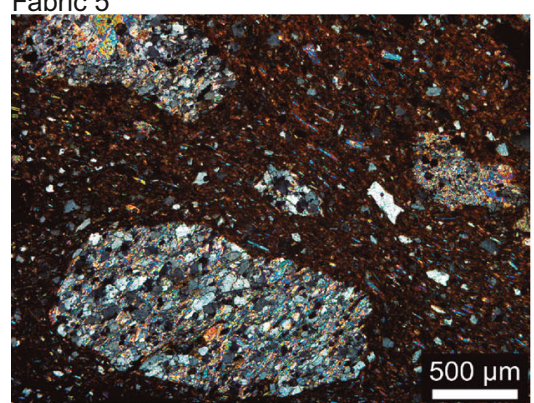

Fabric 7

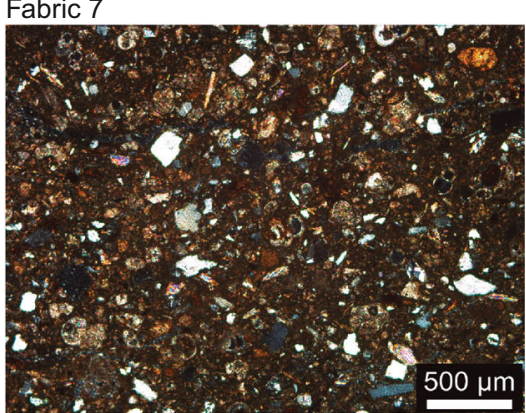

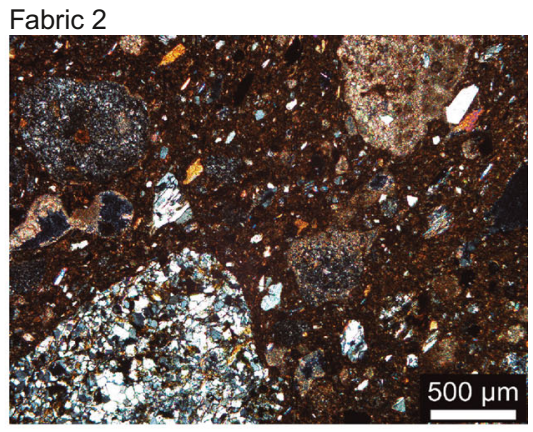

Fabric 4

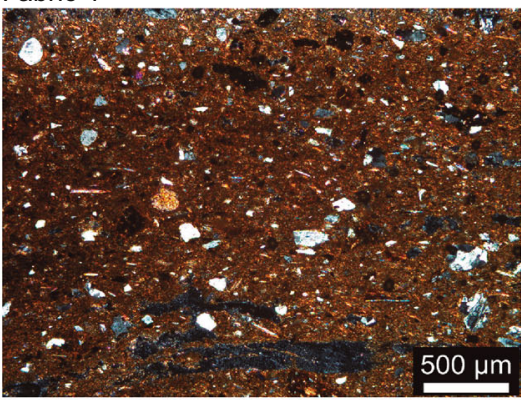

Fabric 6

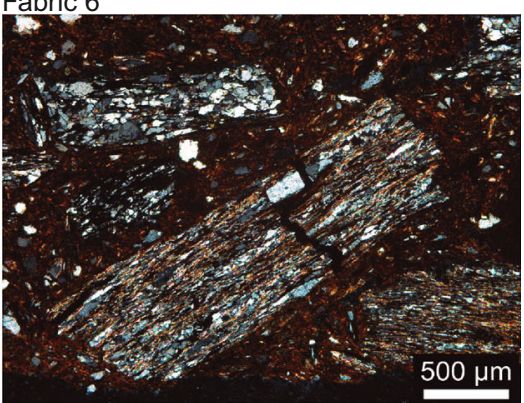


Fabric 1: fine-grained, non-calcareous matrix (c:f: $\mathrm{v}_{10 \mu}=10: 85: 5$ to 15:75:10) (MPL-007, MPL-017 and MPL-025) with a characteristic well (MPL-007) to moderately sorted (MPL-017 and MPL-025) aplastic grain size distribution. The composition and texture of the inclusions are typical of secondary deposits resulting from the decomposition of metamorphic materials due to depositional processes, with quartz $(\leq 0.3 \mathrm{~mm})$, white mica $(\leq$ $0.3 \mathrm{~mm}$ ), metamorphic rock fragments (mica schist and quartzite, $\leq 1.1 \mathrm{~mm})$, opaques $(\leq 0.2 \mathrm{~mm})$, brown mica $(\leq 0.4 \mathrm{~mm})$, tourmaline $(\leq 0.1 \mathrm{~mm})$, zircon $(\leq 0.1 \mathrm{~mm})$ and epidote group minerals $(\leq 0.1 \mathrm{~mm})$. The matrix of those samples is formed by a non-calcareous, silty, micaceous groundmass, red-brown to pale brown in planepolarised light (PPL), with firing horizons (MPL-007 and MPL-017), and inclusions strongly oriented subparallel to the surface of the vessels. Characteristic of this group is the presence of $\mathrm{D}+\mathrm{TF}$, and mega planar voids are strongly oriented parallel to the vessel surface. The latter are probably connected to the forming technique employed (Fig. 6a).

Fabric 2: sandy limestone, metamorphic material and andesite (c:f: $\left.\mathrm{v}_{10 \mu}=25: 70: 5\right)$ (MPL-022). Heterogeneous and unsorted aplastics oriented parallel to the surface at the margins. Main inclusions are sandy limestone (containing metamorphic rock fragments and quartz, $\leq 1.5 \mathrm{~mm}$ ), low to medium metamorphic rock fragments (phyllite, quartzite and mica schist, $\leq$ $2 \mathrm{~mm}$ ), intermediate volcanic rock fragments (andesite, $\leq$ $1.9 \mathrm{~mm})$, microfossils $(\leq 1 \mathrm{~mm})$, green clino-amphibole $(\leq$ $0.6 \mathrm{~mm})$, tourmaline $(\leq 0.3 \mathrm{~mm})$ and white mica $(\leq 0.2 \mathrm{~mm})$, along with diverse accessory minerals. The matrix of the sample is slightly calcareous and fairly silty, without a clear orientation. The groundmass is slightly active with barely appreciable firing horizons; its colour varies from brown to orangebrown in PPL.

Fabric 3: low- and medium-grade metamorphic materials in a marly groundmass (c:f: $\mathrm{v}_{10 \mu}=15: 80: 5$ to $35: 60: 5$ ), comprising six samples from phase 8 (MPL-101, MPL-102, MPL-108, MPL-109, MPL-112, MPL-113) and three from phase 9 (MPL-004, MPL-012 and MPL-018). Inclusions moderately to locally orientated, in one sample, a relict coil is evident (MPL-018), with moderately sorted and bimodal distribution. Coarse fraction (mainly $3.8-0.3 \mathrm{~mm}$ ) refers chiefly to elongate dark phyllite and schist fragments and quartzite $(\leq 3.8 \mathrm{~mm})$. Less common are quartz $(\leq 2.4 \mathrm{~mm})$, opaques $(\leq 1.2 \mathrm{~mm})$, brown mica $(\leq 0.6 \mathrm{~mm})$, microfossils $(\leq 1 \mathrm{~mm})$ and white mica $(\leq$ $1.3 \mathrm{~mm}$ ). Fine fraction contains quartz, microfossils and white and brown mica. Inclusions are surrounded by a fine-grained calcareous, light brown-coloured matrix, which is optically inactive to slightly active. Voids are mainly represented by vughs and vesicles.

Fabric 4: fine metamorphic in a calcareous matrix, low in microfossil content (c:f: $\left.\mathrm{v}_{10 \mu}=10: 85: 5\right)$ (MPL-011). Aplastics are moderately sorted and locally orientated parallel to surfaces. Main inclusions are quartz ( $\leq$ $0.5 \mathrm{~mm})$, white mica $(\leq 0.4 \mathrm{~mm})$, metamorphic rock fragments (schist, phyllite, $\leq 1 \mathrm{~mm}$ ), calcareous inclusions (microfossils and intraclasts, $<0.6 \mathrm{~mm}$ ), clay-rich sedimentary rocks $(\leq 0.7 \mathrm{~mm})$ and opaques $(\leq 0.5 \mathrm{~mm})$. The groundmass is formed by a yellowish calcareous matrix, which is optically active.

Fabric 5: mica schist bearing garnet porphyroblasts (c:f: $\mathrm{v}_{10 \mu}=20: 75: 5$ to $35: 55: 10$ ), one sample from phase 8 (MPL-105) and five samples from phase 9 (MPL-008, MPL006, MPL-010, MPL-014 and MPL-020). These are characteristic light-coloured mica schist and quartzite bearing coarse garnet porphyroblasts, although with some textural variability. Metamorphic rock fragments in MPL-008 are coarse-grained quartzite grains $(\leq 3.7 \mathrm{~mm})$, while MPL-006, and especially MPL-010 and MPL-014, is finer grained with a higher proportion of mica schists $(\leq 1.9 \mathrm{~mm})$. Most common inclusions are quartz $(\leq 0.5 \mathrm{~mm})$, white mica $(\leq 0.8 \mathrm{~mm})$ and the aforementioned metamorphic rock fragments (schist and quartzite), the latter containing characteristic mineral phases, such as kyanite, tourmaline, garnet, epidote and zircon, also present as discrete inclusions in the fabric. The silty micaceous matrix displays firing horizons from orange-brown to dark brown in
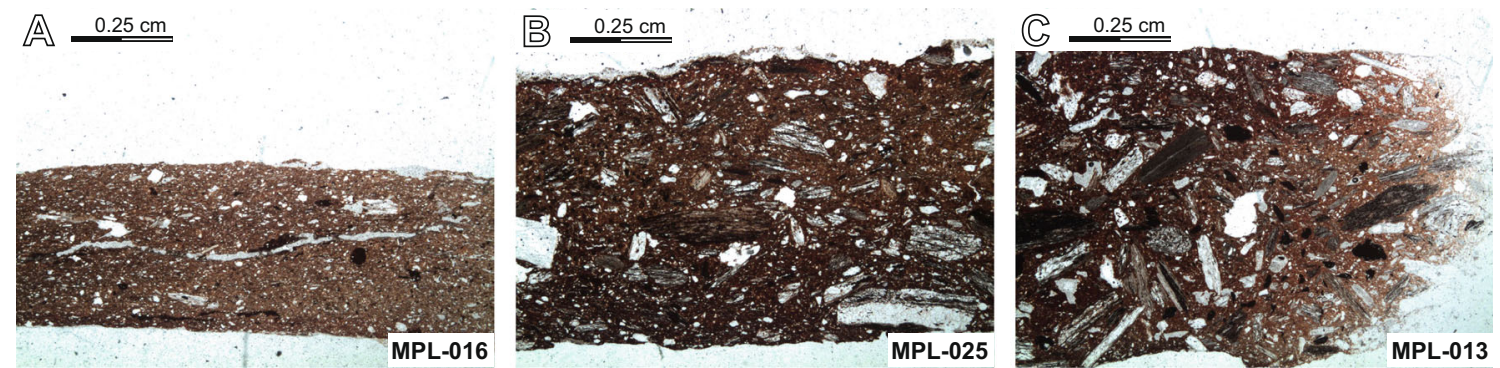

Fig. 6 Micrographs illustrating evidence for forming techniques, thin sections and PPL. a Elongate voids as described for fabric 1. b Elongate inclusions orientated parallel to the vessel surface in a domestic pot, fabric 6. $\mathbf{c}$ Relict coil, fabric 6 
PPL, although MPL-020 is characterised by a finer brown matrix. The matrix is optically active (MPL-020), through being active to slightly active (MPL-006, MPL-008 and MPL-014). Elongate voids (cracks and channels), strong to moderately oriented parallel to the wall surface, are characteristic, as well as mega vesicles, probably related to firing temperature and forming technique.

Fabric 6: phyllite and schist (c:f: $\mathrm{v}_{10 \mu}=20: 75: 5$ to 30:60:10), the main petrographic group, with 32 samples, including domestic and metallurgical ceramics (all the crucibles and the blowpipe nozzle) from both phases under study. The most striking characteristic of this group is the high abundance of coarse aplastics, dominantly dark, elongate fragments of low- to medium-grade metamorphic rocks (phyllite and, less commonly, mica schist and quartzite), probably bearing graphite and metallic oxides (ca. $\leq 4 \mathrm{~mm}$ ). The inclusions in these samples exhibit a bimodal distribution and a coarse texture except for MPL-104, in which the coarsest fraction is absent, reflecting some internal textural variability. Other inclusions in this fabric are quartz $(\leq 1.6 \mathrm{~mm})$, white mica $(\leq 0.8 \mathrm{~mm})$, brown mica $(\leq 0.7 \mathrm{~mm})$ and opaque minerals $(\leq 1.6 \mathrm{~mm})$. The main metamorphic inclusions are similar to those described in fabric 3 . However, in fabric 6 , the aplastics are surrounded by a non-calcareous, silty micaceous groundmass, red brown to dark brown (PPL), affected by firing horizons.

Regarding other technological and functional aspects, the orientation of the aplastics in fabric 6 is variable, often moderately to strongly oriented (Fig. 6b) (exceptions are MPL-023 and MPL-024, whose orientation is predominantly local to absent). This is probably related to the forming techniques employed and the frequency of the use of moulding. Nevertheless, another four samples show signs of relict coils in the upper part of the body (MPL-09, MPL-013, MPL-0106 and MPL-110) (Fig. 6c).
Regarding optical activity, all the crucibles had been used and a temperature gradient is observed across the wall, related to their function. Their inner surface, where slag adheres, is highly vitrified and is characterised by abundant boating pores, while the degree of vitrification decreases towards the exterior of the vessels (Fig. 7). The domestic vessels show different degrees of activity, from active (MPL-003, MPL-005, MPL-010, MPL013, MPL-016, MPL-019), through slightly active (MPL-001, MPL-002, MPL-009, MPL-024, MPL-104, MPL-106, MPL110 and MPL-111), to inactive (MPL-103, MPL-107, MPL015).

Fabric 7: Marl (c:f: $\mathrm{v}_{10 \mu}=30: 60: 10$ to $40: 50: 10$ ) is formed by four samples, two from phase 8 (MPL-114 and MPL-115) and two from phase 9 (MPL-021 and MPL-116), of which none of them are ceramics. Microfossils (mainly globigerina, $\leq 6.4 \mathrm{~mm}$ ) are dominant, mainly medium to very fine grained. Other common inclusions are elongate crystals of white mica $(\leq 0.6 \mathrm{~mm})$, quartz $(\leq 0.5 \mathrm{~mm})$ and D+ orange-brown inclusions $(\leq 0.3 \mathrm{~mm})$. Rock fragments are very few, being bioclastic limestone $(\leq$ $3 \mathrm{~mm}$ ) and metamorphic rock fragments (phyllite and quartzite, $\leq 0.8 \mathrm{~mm}$ ). Its matrix is formed chiefly by micrite, yellowish brown in PPL and optically active. Mega-microvughs and macro-meso-planar voids are present.

\section{SEM}

SEM observations were only carried out on domestic ceramics, aimed at the assessment of firing conditions. A microanalysis of the groundmass, avoiding coarse inclusions, was run in order to obtain a qualitative indication of its $\mathrm{Ca}$ content, to be compared with petrographic observations. A distinction can be made between samples with higher $\mathrm{Ca}$ concentrations (F2, F3 and F4) and low calcareous fabrics (F1, F5 and F6) (Fig. 8). Most of the samples showed microstructural traits
Fig. 7 Micrographs on crucibles. a Different degrees of vitrification from the inner surface (top) to the outer surface (bottom). b Vertical section of a crucible showing a fatal crack filled by copper slag during the production process
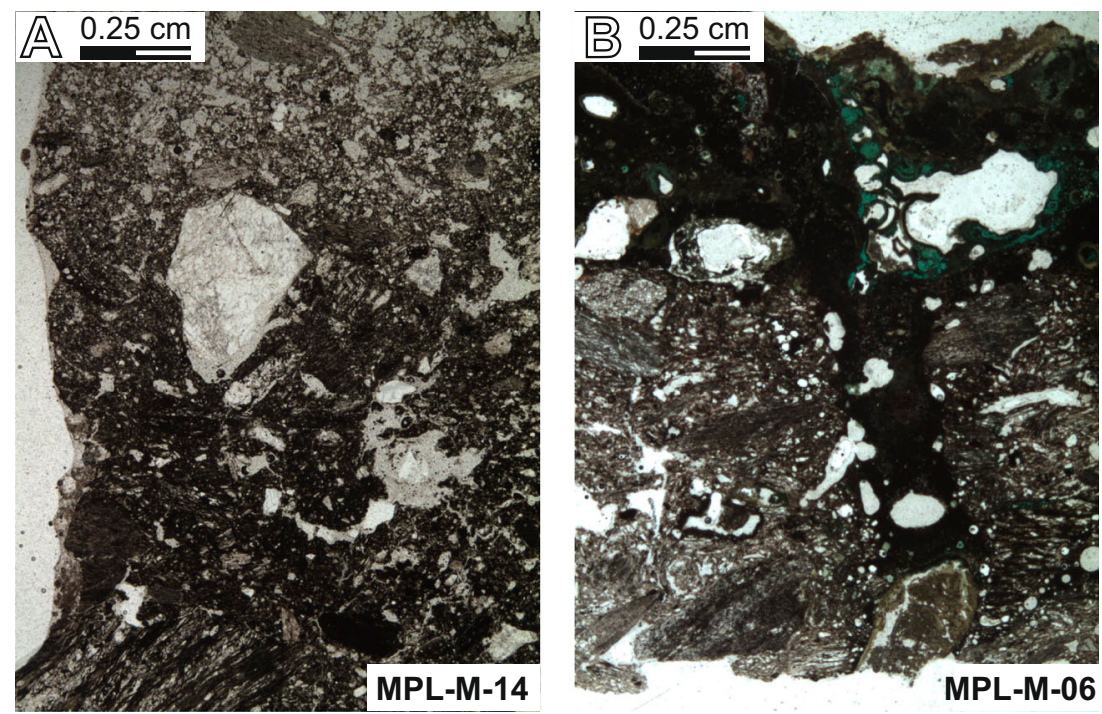

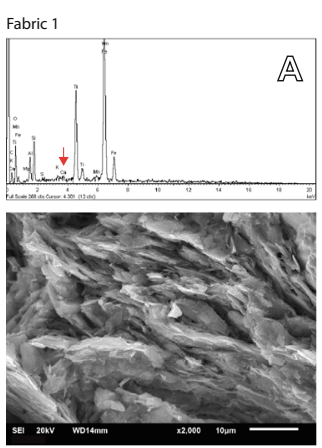

Fabric 2
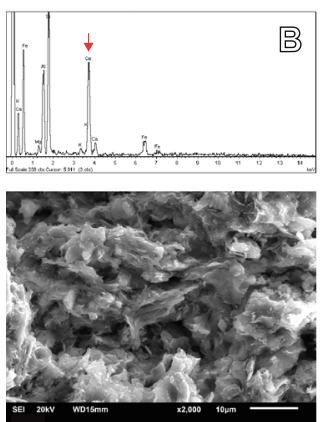
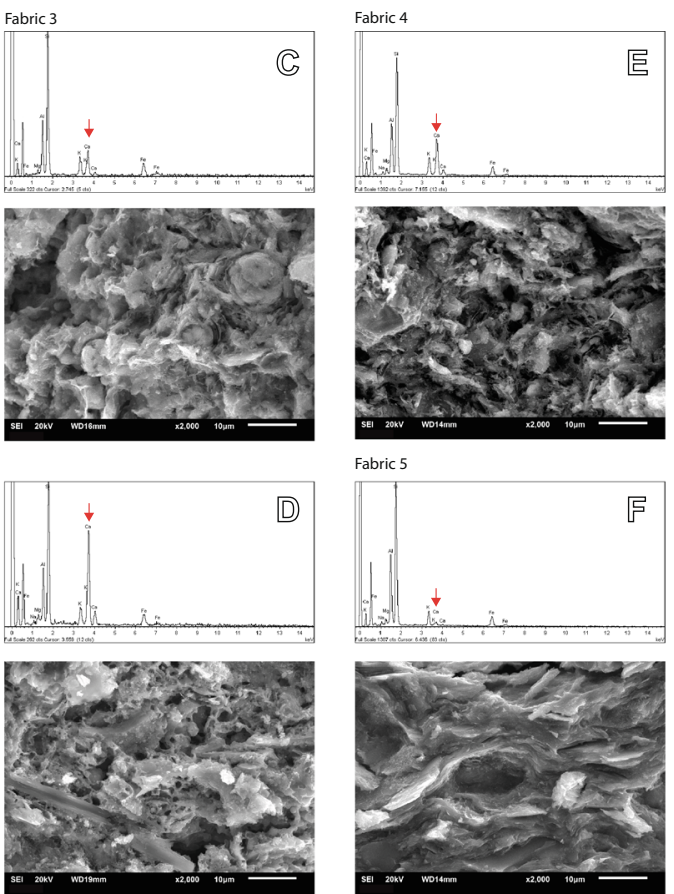

Fabric 5
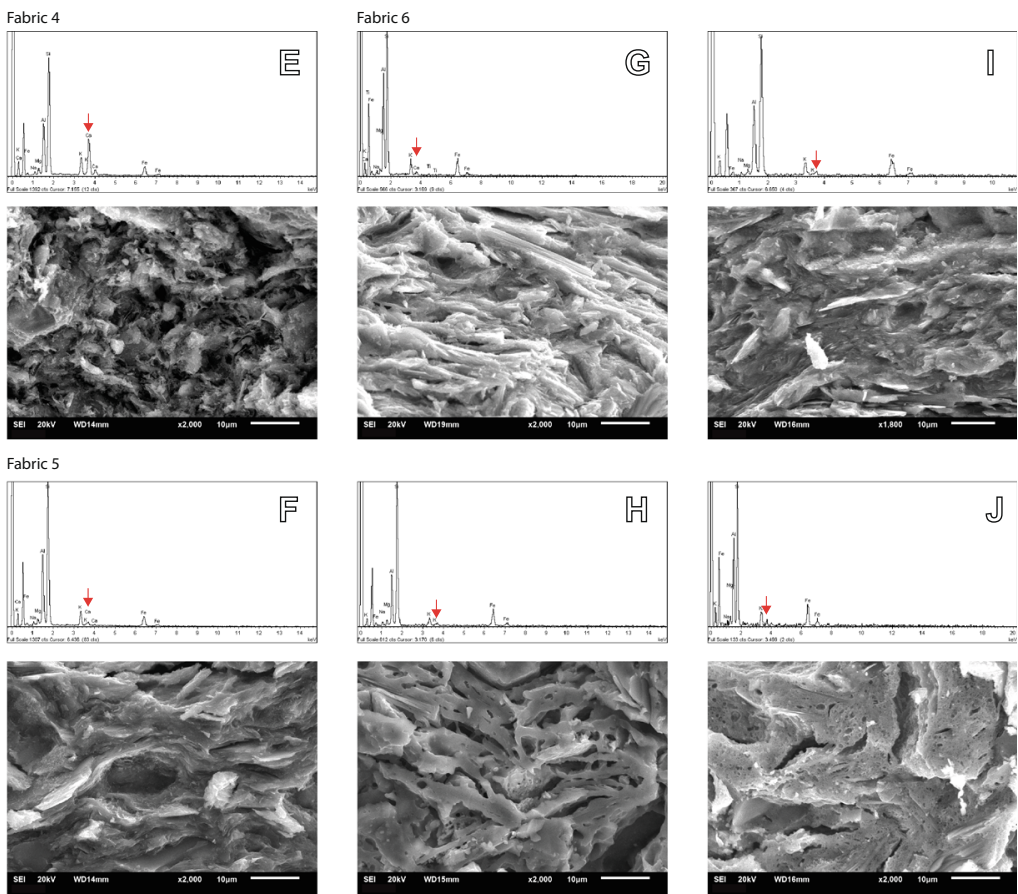

Fig. 8 a-j Representative of SEM micrographs and EDX spectra referred to sintering stages identified within each fabric. Arrows indicate main Ca peak in each spectrum where the $x$-axis represents element-specific fluorescent energies and the $y$-axis represents detected intensity

typical of non-vitrified groundmasses through initial vitrification (Table 1), independent of their composition or macroscopic ceramic group. As expected, the microtexture of these samples underwent different changes according to their $\mathrm{Ca}$ content, in a way used to estimate equivalent firing temperatures (Heimann and Maggetti 2014; Maniatis and Tite 1978, 1981).

Calcareous samples showed either a lattice structure, typical of a non-vitrified groundmass (below $750{ }^{\circ} \mathrm{C}$ ) (Fig. 8b, c, e), or the incipient cellular structure of a stage of incomplete vitrification (Fig. 8d), due to the thermal decomposition of calcite, indicating that firing probably occurred in excess of $800{ }^{\circ} \mathrm{C}$, but below $900{ }^{\circ} \mathrm{C}$, when extensive vitrification should be achieved. Low calcareous fabrics exhibit a wider range of sintering and vitrification stages. A number of samples exhibited the remaining layered structure of the phyllosilicates that form the groundmass (Fig. 8a, g), related to estimated firing temperatures below $750-800{ }^{\circ} \mathrm{C}$, depending on redox conditions. An increasing densification can be observed also in samples that have undergone a higher degree of thermal alteration, with partial melting of the edges of the platy components of the matrix $\left(800-900{ }^{\circ} \mathrm{C}\right)$ (Fig. 8f, i), and a molten phase extensively present in a limited number of individuals $\left(900-1000{ }^{\circ} \mathrm{C}\right)$ (Fig. 8h). Moreover, four samples belonging to $\mathrm{F} 5$ and $\mathrm{F} 6$ exhibited bloating pores on their external surface (Fig. 8j), an indication of fast firing where the fuel was located close to the exterior of the pot.

\section{Technological and compositional variability and the relation to typological and functional groups}

Clay-rich materials in Las Pilas testify to a number production processes. These are represented by production sequences that comprise a range of similarities and differences, in relation to raw material textures and composition, forming techniques and firing conditions, all of which were combined in different ways. The comparison between the two occupation phases under analysis attests to some continuity in those processes over time.

There is no discernible, neat distinction between ceramic groups, in terms of the use of different choices and manipulation of raw materials that correspond to functional ceramic groups (such as common ware, metallurgical ceramics and prestige vessels). As depicted in Fig. 9, large petrographic groups such as F6 include almost every ceramic type examined. A similar pattern is repeated in the fabrics containing more than one individual (i.e. F1, F3 and F5).

One clear pattern does stand out, however, in the correlation between the relative calcareous content of a fabric and its general type. Building materials and the piece of formed, unfired clay tend to comprise marly sediments with microfossils embedded in a micrite-rich groundmass. The composition of some ceramic fabrics identified exhibits a clear resemblance to these unfired fragments, with the exception of the addition of phyllite as an aplastic in the pottery. In contrast, Ca-rich fabrics are completely absent from any technical ceramics, and these are made of the same fabric as that principally used in domestic ware. 
Fig. 9 Distribution of samples according to their petrographic fabric and macroscopic classification, data reported in Table 1. The difference in colour represents the two archaeological phases analysed in the paper. $\mathrm{b} / \mathrm{s}$ body sherd

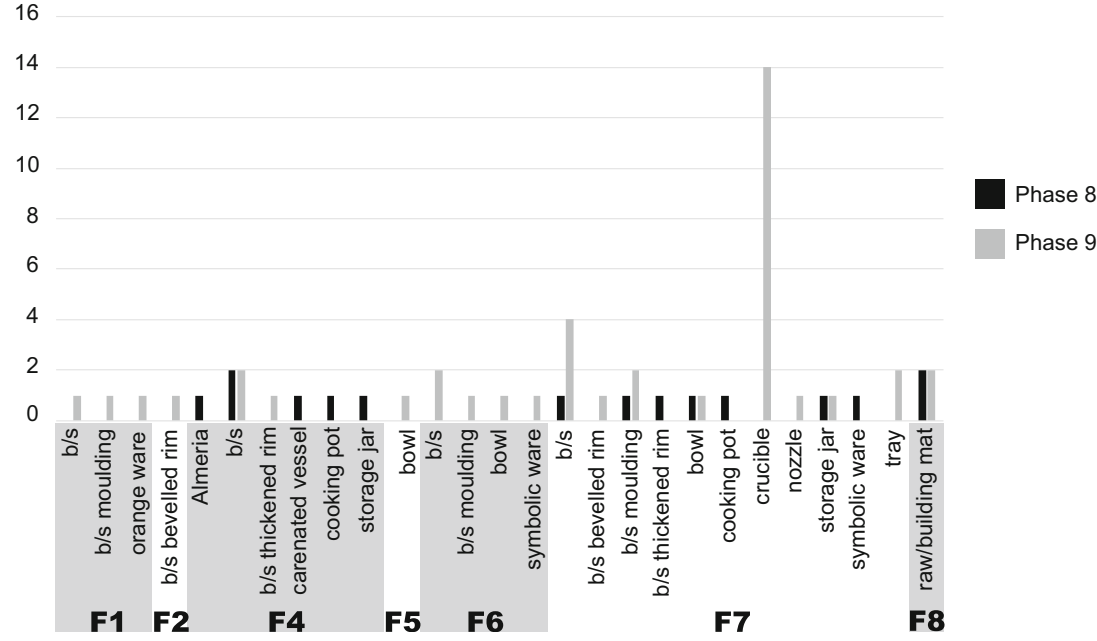

With regard to forming techniques, our observations support previous data, which suggest that open vessels, such as platos, bandejas and crucibles, were mainly formed by means of either pressing clay into moulds or using other tools, while smaller and higher-walled vessels, such as cuencos, exhibit microtextural traits of coiling (Camalich Massieu and Martín Socas 1999; Inácio et al. 2013). Such a combination of moulding and coiling is clear in the sample MPL-013.

These results point to fabrics exhibiting a low degree of thermal alteration, probably as a result of short firing processes undertaken in simple structures in which firing conditions were poorly controlled and varied within a single firing event (Gosselain 1992; Livingstone Smith 2001; Maggetti et al. 2011). This also matches with the presence of firing horizons, as referred to in the petrographic descriptions, and the occurrence of common dark stains on the surface of the vessels, often visible on the coarse ware. When compared with petrographic fabrics, these differences do not seem specific to any group. In addition, those fabrics with the higher numbers of samples are those that exhibit also higher variability (i.e. F3 and F7), which supports the idea of these variations resulting from irregular firing conditions. Nevertheless, this lies in contrast to the careful firing evident in the ceramics classified as prestige vessels, such as the symbolic and orange ware. To an extent, these are equally variable in respect of firing temperatures, but their fairly regular colouration reflects a certain care for redox conditions, probably locating them in places within the firing structure where these pots were protected from contact with fuel and flames.

With regard to provenance within the region of study, the results show the use of different raw materials whose source can be suggested and are discussed in the following section.

\section{Discussion}

With the analytical results in mind, we can consider the insights they offer into the development of metallurgy in southern Iberia, an area which plays a crucial role in the definition of the pathways towards social complexity in Western Europe. Settlement patterns, funerary rituals and accompanying material culture have been understood as major sources of evidence for Chalcolithic economy and social structure. The same remains testify to disparities in the pace and direction of social change, and yet the discourse is still dominated by general statements rather than detailed characterizations of local patterns.

When detailed work has been carried out on material culture, the focus has been metalworking itself, with the redefinition of variation in technical choices and knowledge transmission at regional and even local scales in the last few decades. What has been rarer is an assessment of how these differences in metallurgical tradition are entangled with other social and material transformations within these communities. Ceramic technology, for example, regardless of its importance in the definition of the Chalcolithic-type assemblage, is poorly known in terms of production, distribution and consumption patterns, and a number of different hypotheses have been put forward regarding levels of specialisation. As a result, most of the debate on the relation between technological and social changes has been grounded in the analysis of metallurgy that, despite its obvious importance, represents only a small portion of the material living conditions of Chalcolithic groups in Iberia. This discussion is focussed on the site of Las Pilas framed within SE Spain, but references to other areas of $\mathrm{S}$ Iberia will be included, as they are the only comparative material available.

\section{Provenance implications}

A comparison of the ceramics and clay-rich materials with the surrounding geology suggests that the procurement, manufacture and, where relevant, exchange took place within a "local" context. Opaque-rich phyllite outcrops matching the fragments identified in the pottery and metallurgical ceramics 
are present within the Alpujárride complex of the Cabrera mountain range. In the foothills, in the areas where the site is located, there are Tertiary marl deposits with globigerina microfossils and sandy calcite-rich rocks. The use of these materials in the building of shelters at the site also supports this fabric's local origin. Equally, extensive outcrops of lightcoloured garnet mica schists are common components of some of the oldest outcrops of the Alpujárride complex. This suggests that fabrics $3,4,5$ and 6 represent a range of clay-rich resources from the phyllite-rich eroded materials from the Cabrera range to the marly deposits downslope. It should be noted also that layers of carbonate-rich material occur among the metamorphic outcrops, introducing some complexity to this picture.

Fabrics 1 and 2 present marked compositional and textural peculiarities. The abundance of fine, mono-mineralic inclusions in fabric 1, mainly quartz, opaque minerals, zircon and tourmaline, can be linked to fluvial deposits. The nearest compatible source is the Aguas River deposits, about $800 \mathrm{~m}$ north from Mojácar, very close to Las Pilas. The origin of fabric 2 is more difficult to determine geographically. However, the presence of phyllite and carbonate rock fragments resembles the composition of fabrics 3, 4 and 5, the main difference being the occurrence of igneous material of intermediate composition. This fabric might derive from slightly further away, since andesitic material outcrops are located ca. $10 \mathrm{~km}$ south of the site and are equally close to materials of the Alpujárride complex (Espinosa Godoy et al. 1974a, 1974b).

These results point to most clay-rich resources employed being available within a radius of ca. $1 \mathrm{~km}$ from the site. Therefore, it seems likely that the ceramic materials were produced either in the settlement of Las Pilas or nearby, in contrast to the previous research which suggested that ceramic materials from the site of Campos, located in the north of the Vera Basin, in Cuevas del Almanzora, were transported roughly $17 \mathrm{~km}$ distant from Mojácar (Echallier 1999). This implies that the role of Las Pilas is rather different from that described for Zájara and Campos, whose ceramics were argued to have been mostly produced elsewhere and imported to the sites.

Petrographic analysis of materials from Campos pointed to the presence of a number of fabrics (groups 1,2 and 3 in Echallier 1999) in which metamorphic materials were abundant, with some variation in the proportion of low- to medium-grade metamorphic rocks (phyllite and schist) and detrital carbonaceous material (mainly foraminifera). The area of Mojácar was suggested as a possible origin, and indeed, our petrographic analysis might support this hypothesis. However, these results can be only considered preliminary, since a detailed comparative analysis would be needed to confirm the hypothesis. At present, the knowledge of other Chalcolithic sites in the area is rather limited in terms of pottery production and consumption.
In addition, some discrepancies between the fabrics proposed in Campos and those defined for Las Pilas should be considered. While the presence of calcareous inclusions (mainly foraminifera) was considered as a distinctive element to differentiate phyllite and schist-rich groups 1 and 2 in Campos, in Las Pilas, they are all considered as part of fabric 6, since calcareous inclusions appear as lesser components and may reflect natural variability within a source. In contrast, in Las Pilas, fabrics 5 and 6 are separated according to textural and compositional differences, specifically the content of opaque and ferromagnesian minerals within the phyllite/schist fragments, or the presence of coarse garnet porphyroblasts and well-formed index minerals, such as kyanite. Nevertheless, gneiss/mica schists characterised by the presence of garnet and kyanite appear in Campos as part of group 1, among phyllite-rich samples. These compositional and textural traits are crucial to differentiate Palaeozoic from Permian to Triassic materials within the Alpujárride complex and, hence, possible differences in origin.

Not all the samples from the site of Campos can be linked to Las Pilas, as group 2 of Echallier (metamorphic materials) contains grog, which is not present in samples analysed from Las Pilas. However, this is only one out of 42 samples rich in metamorphic materials and clearly represents different technological practices and, perhaps, sources, as the wider region of Andalusia is dominated by similar geology. More abundant in Campos is another fabric tempered with grog in a Ca-rich groundmass (group 4). This group contains chiefly marly components, which seem different from those found in Las Pilas, according to their content of ostracods and bivalves, as well as their grog tempering.

\section{Technological practice in clay-rich materials}

The Las Pilas ceramic assemblage also provides insight into the role of technology in the construction of the material conditions that made certain social structures possible. By comparison with other case studies, we might consider questions of a Chalcolithic ceramic tradition in the study area and its relation with neighbouring regions.

Metalworkers at Las Pilas opted to use non-calcareous, coarse fabrics in thick-walled crucibles. In the use of blowpipe technology, the crucible needs to be insulated, in order to avoid heat loss, and a thick wall would aid this, while a coarse recipe adds to toughness and resistance against thermal shock.

More specifically, the crucibles were heated from above and are highly vitrified on their inner surface, where copper alteration products are present, while a temperature gradient can be observed as the outer surface exhibits higher optical activity. The use of non-calcareous pastes, instead of the $\mathrm{Ca}$ rich materials used elsewhere in Iberia, has a variety of important implications in terms of their production and use. From 
$900{ }^{\circ} \mathrm{C}$, low-calcareous material suffers strong microtextural changes derived from groundmass sintering, and this process and subsequent vitrification lead to high proportions of melted phases within the ceramic body around $1100^{\circ} \mathrm{C}$, which eventually would lead to the vessel's collapse. In contrast, Ca-rich materials develop a characteristic cellular structure, which is still present at similar temperatures (Hein et al. 2008; Heimann and Maggetti 2014). The choice of Ca-poor raw materials for metallurgical ceramics, even though calcareous clay-rich materials were available near the site, represents a stark contrast from the practice documented in western Andalusia at broadly the same time (Nocete et al. 2008; Inácio et al. 2011).

Temperatures necessary to melt most common metals range from 900 to $1200{ }^{\circ} \mathrm{C}$, normally operating at temperatures around $1100{ }^{\circ} \mathrm{C}$ (pure copper melts at $1083{ }^{\circ} \mathrm{C}$ ) (Martinón and Rehren 2014), which, in Las Pilas, would push the crucibles to their limit. In fact, one of the samples analysed suffered from a fracture during the melting process as a consequence of its use. In this sense, the resistance to fracture propagation was improved following a strategy based on the presence of elongate inclusions that, due to the most common forming technique employed in the area, moulding, were strongly oriented parallel to the vessel surfaces. In the same way, matrix shrinkage produced during the sintering process occurred due to the high temperatures achieved by the ceramic during their use, leading to numerous crack-type voids within highly tempered (?) vessels. All these factors are well-known contributors to thermal conductivity and toughness in ceramic materials (Hein et al. 2008; Müller et al. 2010). This markedly different behaviour of ceramic components, depending on their shape and composition, and the specific knowledge needed in each case to attain the production of usable crucibles might have been, in part, responsible of the low petrographic variability showed by metallurgical ceramics when compared to domestic wares.

Nevertheless, it is noteworthy that most of the crucibles analysed share their production process with domestic pots in terms of shape (fuentes), some of which were used for roasting cereals, as well as raw material selection, through forming techniques, and possibly firing (Montero Ruiz 1993; Rovira 2002). It suggests that, contrary to expectations, metallurgical ceramics were not part of a separate production process but, instead, were products of practices very similar to those employed in common ware.

In contrast, the vessels classified as prestige goods belie suggestions of a unique, centralised production location, as they have different fabrics. They were finished with special care, resulting in highly polished surfaces or homogeneous colour, as is the case in most of SE Iberia. In that much, the prestige ceramics are similar to the domestic ceramics in sharing a source but show how common raw materials could be converted into goods bearing high symbolic value through human action and, by extension, how production processes were involved in the politics of ostentation as society underwent change. This process of transformation from common raw materials to prestige goods and the homogenisation of their appearance are also important, probably reflecting the emphasis put in their social role (Kohring et al. 2007).

This apparent transformation, from common raw materials to valuable goods, makes these ceramics a special case among prestige goods, as the other materials traditionally employed for this (amber, ivory and rare minerals) seem to have contained a high symbolic meaning even without mediating any crafting process, as they are used as grave goods (García Sanjuán et al. 2013).

\section{Social implications}

Our analysis suggests that ceramic production and consumption in Las Pilas was mainly a local phenomenon. While future work should concentrate on similar studies in neighbouring sites, in order to build on these indications, it seems clear that some of the practices recorded here have their origins in the Neolithic. The ceramics used in metallurgical practices certainly do not give the impression of being very different from other pottery manufactured and used in the area.

Perhaps the characterisation of metallurgy as a catalyst of social change would lead us to expect that the most evident differences in terms of production processes in the area would be present in technical ceramics, such as the crucibles. However, far from suggesting different, concealed knowledge, the metallurgical ceramics seem very similar indeed to domestic ceramics, if not sometimes indistinguishable. If anything, we would draw attention to the careful treatment of prestige ceramics, which were the result of distinct production processes that converged in terms of surface finishing, decoration and firing, in order to achieve a similar effect in spite of their varied raw materials. This action to produce a specific surface effect is arguably more consistent with the needs of display in an increasingly competitive social environment. Perhaps the symbolic value of these vessels would imply lower tolerance towards undesired variations in shape, colour, texture, etc. This has been identified in other contexts as signs of part-time specialisation (Longacre 1999; Day et al. 2010; Salanova 2012). This role of prestige and personal adornment goods as a catalyst for new forms of labour distribution within late prehistoric communities seems to be a tendency that started in the Neolithic in Cabecicos Negros (Goñi Quinteiro et al. 1999). It might also be testified in the Chalcolithic in SW Iberia in the production of highly symbolic or ritual goods, such as idols (Thomas 2009). Such a tendency may have continued during the final phases of the Chalcolithic, with the production of Bell Beakers (Kohring et al. 2007) and into the Bronze Age (Aranda Jiménez 2004). 
However, we should keep in mind that this group of vessels, in any case, would not amount to more than a small proportion of the total ceramic record. Taking as a reference the sites of Zájara and Campos, these prestige wares represent less than $1 \%$ of the sherds considered for typological classification (Camalich Massieu and Martín Socas 1999). Even when their proportion may be higher in funerary contexts (Martín Socas and Camalich Massieu 1982), it seems likely they result from a small and heterogeneous production that relied on highly skilled individuals involved in the production of other ceramic goods and other economic activities on a routine basis. Hence, correspondence in ceramic traits among different sites probably suggest a common background of acculturation, rather than to some centralised production based on specific workshops.

Finally, the identification of fabrics in Campos similar to those identified in Las Pilas points to the possibility of pottery products at one site being intended for use in another. Important questions arise from this, for example whether all ceramic classes were exchanged in the same way. Did symbolic materials travel further than common ware? We are beginning to produce the data to answer such questions.

\section{Metalworking inception and the definition of technical traditions}

The levels analysed in Las Pilas represent a moment in which metallurgy was becoming entrenched as part of everyday life in SE Iberian communities, at least in terms of its presence, more than in sheer volume. The ceramics contribute to an understanding of how this process occurred. Firstly, the majority of the ceramic types present in Chalcolithic pre-Bell Beaker contexts in SE Iberia do not indicate a rupture with ceramic technology of previous periods. In addition, the research shows that metallurgy does not seem to have been accompanied by the introduction of ceramic technological innovation in terms of specific production processes. In consequence, the importance of the indigenous material culture in metalworking contexts could be indicative of an active role of these populations in metalworking inception, if indeed there is any reason to think of the move to metallurgy as being the product of the movement of human groups. The abundance of prestige goods made in the same way as previously implies a different system of values, which did not change radically after the introduction of metallic goods.

It is of interest that pottery of Almería type, such as that identified in Las Pilas, comprises a red-slipped shape already present in Neolithic levels, and that the schematic motifs in symbolic ware also have their origins in the earlier period. In contrast to this, examples from other parts of Europe refer to the important implications of metallurgy in other aspects of material culture (Radivojević and Rehren 2016). Similarly, in mainland Greece, graphite-painted wares appear in association with metal-bearing contexts, perhaps a sign of contacts with neighbouring populations from the Balkans (Zachos 2007). Our point here is that external influence and influx cannot always be assumed when seeking to produce syntheses across extensive geographical areas. Seemingly contrasting local sequences such as that at Las Pilas should be taken into account. Variability in cultural and technological transmission should be interpreted, and these detailed accounts of practice should not be brushed over.

Furthermore, we should be wary of how any study of transmission, diffusion and adoption benefits from looking at as a broad range of material across the technological spectrum, something which our own disciplinary divides often discourage. Models of technology transfer based on "itinerant smiths" rely on the role of metals as a status marker and the conception of metalworking as a new, restricted knowledge. At least in the case of metallurgical ceramics at Las Pilas, the production process of these objects does not differ greatly from domestic ware. On the contrary, in our case, they resemble the vessels used to roast cereals from Neolithic contexts.

In short, this challenges us to examine communities as loci of technological practice involving a variety of materials, even as we acknowledge that the arrival of metallurgy is an important factor in social and political transformation. In this sense, ceramic technology seems to show traces of a collective, at least local identity that somehow is transmitted into metallurgical practice, a picture perhaps compatible with archaeometallurgical data from the same site (Murillo-Barroso et al. 2017).

\section{Conclusions}

Local practices are basic to addressing innovation and knowledge transmission processes, and they are equally fundamental in the construction of cultural and social boundaries on an everyday basis. Nevertheless, aspects such as the consolidation of long-distance exchange networks and technological change have played the central role in the explanations of social change during the Chalcolithic in SE Iberia. As a result, these questions have been often addressed from top-down models that need to be weighed against the emerging wealth of locally contextualised analytical understandings of past production and indeed consumption in the area. Therefore, the understanding of traditional materials and local contexts, especially with a diachronic dimension from the Neolithic, continues to be vital to understand the conditions in which Chalcolithic economic and social change occurred.

In these terms, it might have been anticipated that striking changes in material culture, such as the appearance of metallurgy, could have encouraged other important technological changes in the manufacture of other goods. Given the importance often conferred on metalworking as a practice reliant on 
highly symbolic and restricted knowledge, it might also be expected that these changes related also to the value placed up its products. Metalworkers and their products might be thought likely to stand apart due to the extreme conditions of their production. Equally, the functional diversity of SE Iberian Chalcolithic assemblages might be expected to have produced compositional and technological variability, certainly in comparison to the Neolithic. It has been suggested that such changes would have economic implications, such as in the organisation of labour, important to emerging social structures. In the Vera Basin, this has been thought to lead to the development of increasingly hierarchical cultural groups.

With this in mind, it is of importance that the study of the site of Las Pilas sheds light on the diversity of local contexts in which social complexity emerged, helping us to understand how the construction of local traditions took place within a community across time. It demonstrates the necessity of detailed research on material culture in order to provide empirical grounding for deductions and reconstructions made at a broader scale, such as efforts that aim to approach the transmission of metallurgical practice.

Ceramic production and consumption in Las Pilas was chiefly a local phenomenon, in which clay-rich goods used for different activities were the product of diverse production sequences, not always led by functional needs. Nevertheless, diverse raw materials available in their surroundings were exploited, and the craft persons who collected and mastered them were well aware of their characteristics and their behaviour, especially regarding the challenge of thermal alteration. Moreover, the combination of our results and the archaeological information available points to a knowledge that was managed and kept for generations at a community level rather than to a restricted knowledge, linked to social status. In this social context, especially skilled individuals involved in craft production may have risen to prominence, as social inequality and the politics of display become more important, alongside the demand for prestige goods.

Acknowledgements MPC and PD are indebted to Jaume Buxeda and Marisol Madrid for their guidance in the SEM analysis and the interpretation of microstructural observations. We would like to thank the anonymous reviewers and the editor for their useful comments that have helped to improve the text. Figure 1 has been modified from OpenStreetMap contributors (CC-BY-SA). Mercedes Murillo Barroso kindly supplied us with the photographs of metallurgical ceramics included in Fig. 3 .

Funding information This research was funded by the European Commission through a Marie Skłodowska-Curie Individual Fellowship entitled "Technological change at the South-western limits of the Mediterranean basin during the Neolithic and early Chalcolithic: pottery production and consumption" (NEOMEDPOT, number 659466) and by the I+D research project HAR2016-78197-P, by the Spanish Ministry of Economy, Industry and Competitiveness.
Open Access This article is distributed under the terms of the Creative Commons Attribution 4.0 International License (http:// creativecommons.org/licenses/by/4.0/), which permits unrestricted use, distribution, and reproduction in any medium, provided you give appropriate credit to the original author(s) and the source, provide a link to the Creative Commons license, and indicate if changes were made.

\section{References}

Alcaraz Hernández FM (1992) Excavación arqueológica de emergencia en Las Pilas-Huerta Seca (Mojácar, Almería). Anuario arqueologico de Andalucia 3:18-24

Aranda Jiménez G (2004) Craft specialization in pottery production during the Bronze Age in south-eastern Iberia. J Iber Archaeol 6:157-179

Aranda Jiménez G, Lozano Medina A, Camalich Massieu MD, Martín Socas D, Rodríguez Santos FJ, Trujillo Mederos A, Santana Cabrera J, NonzaMicaello A, Clop García X (2017) La cronología radiocarbónica de las primeras manifestaciones megalíticas en el Sureste de la Península Ibérica: la necrópolis de Las Churuletas, La Atalaya y Llano del Jautón (Purchena, Almería). Trab Prehist 74(2):257-277

Budd P, Taylor T (1995) The faerie smith meets the bronze industry: magic versus science in the interpretation of prehistoric metal-making. World Archaeol 27:133-143

Bullock P, Fedoroff N, Jongerius A et al (1985) Handbook for soil thin section description. Waine Research, Albrighton

Camalich Massieu MD, Martín Socas D (eds) (1999) El territorio almeriense desde los inicios de la producción hasta fines de la antigüedad: un modelo, la depresión de Vera y cuenca del río Almanzora, 1st edn. Junta de Andalucía, Consejería de Cultura, Seville

Camalich MD, Martín-Socas D, González P et al (1999) The Neolithic in Almería: the valley of the Almanzora and Vera Basin. Doc Praehist XXXI:183-197

Chapman R (1990) Emerging complexity: the later prehistory of southeast Spain, Iberia, and the west Mediterranean. Cambridge University Press, Cambridge

Chapman R (2008) Producing inequalities: regional sequences in later prehistoric southern Spain. J World Prehistory 21:195-260. https:// doi.org/10.1007/s10963-008-9014-y

Childe VG (1930) The Bronze Age. Cambridge University Press, Cambridge

Day PM, Relaki M, Todaro S (2010) Living from pots? Ceramic perspectives on the economies of prepalatial Crete. In: Langford conference of the Department of Classics (2007: Florida State University), Pullen DJ (eds) Political economies of the Aegean Bronze Age papers from the Langford conference, Florida State University, Tallahassee, 22-24 February 2007. Oxford Books, Oxford, pp 205-229

Delibes G, Díaz-Andreu M, Fernández-Posse MD et al (1996) Poblamiento y desarrollo cultural en la cuenca de Vera durante la prehistoria reciente. Cumplutum Extra 6:153-170

Delibes G, Herrán Martínez JI, de Santiago Pardo J, del Val Recio J (1989) Minería y metalurgía en las antiguas civilizaciones mediterráneas y europeas: coloquio internacional asociado, Madrid, 24-28 octobre 1985, 1st edn. Ministerio de Cultura, Dirección General de Bellas Artes y Archivos, Instituto de Conservación y Restauración de Bienes Culturales, Madrid

Díaz-Andreu M (1995) Complex societies in Copper and Bronze Age Iberia: a reappraisal. Oxf J Archaeol 14:23-39

Dobres M-A (2010) Archaeologies of technology. Camb J Econ 34:103114. https://doi.org/10.1093/cje/bep014

Dolfini A (2013) The emergence of metallurgy in the Central Mediterranean Region: a new model. Eur J Archaeol 16:21-62. https://doi.org/10.1179/1461957112Y.0000000023 
Doonan RCP, Day PM, Dimopoulou-Rethemiotaki N (2007) Lame excuses for emerging complexity in Early Bronze Age Crete: the metallurgical finds from Poros Katsambas and their context. In: Day PM, RCP D (eds) Metallurgy in the Early Bronze Age Aegean. Oxbow Books; David Brown Book, Oxford, pp 98-122

Echallier J-C (1999) Análisis petrográfico. In: Camalich Massieu MD, Martín Socas D (eds) El territorio almeriense desde los inicios de la producción hasta fines de la antigüedad: un modelo, la depresión de Vera y cuenca del río Almanzora, 1st edn. Junta de Andalucía, Consejería de Cultura, Seville, pp 209-221

Eliade M (1978) The forge and the crucible, 2nd. University of Chicago Press, Chicago

Espinosa Godoy JS, Martín Vivaldi JM, Martín Alafont JM et al (1974a) Geological map sheet n. 1032 (Mojácar). Mapa geológico de España E. 1:50.000. IGME, Madrid

Espinosa Godoy JS, Martín Vivaldi JM, Martín Alafont JM, Pereda M (1974b) Report of geological map sheet n. 1032 (Mojácar). Mapa geológico de España E. 1:50.000. IGME, Madrid

Fernández-Miranda M, Fernández-Posse MD, Gilman A, Martín C (1993) El sustrato neolítico en la cuenca de Vera (Almería). Trab Prehist 50:57-85. https://doi.org/10.3989/tp.1993.v50.i0.489

García Sanjuán L, Luciañez Triviño M, Schuhmacher TX et al (2013) Ivory craftsmanship, trade and social significance in the southern Iberian Copper Age: the evidence from the PP4-Montelirio sector of Valencina de la Concepción (Seville, Spain). Eur J Archaeol 16: 610-635. https://doi.org/10.1179/1461957113Y.0000000037

Gavilán Ceballos B (1997) Reflexiones sobre el Neolítico andaluz. SPAL Rev Prehist Arqueol Univ Sevilla 23-33. doi: https://doi.org/10. 12795/spal.1997.i6.02

Goñi Quinteiro A, Rodríguez Rodríguez A, Cámalich Massieu MD et al (1999) La Tecnología de los elementos de adorno personal en materias minerales durante el Neolítico Medio. El ejemplo del poblado de Cabecicos Negros (Almería). SAGVNTVM Papeles Lab Arqueol Valencia Extra 2:163-170

Gosselain OP (1992) Bonfire of the enquiries. Pottery firing temperatures in archaeology: what for? J Archaeol Sci 19:243-259

Harrison RJ, Gilman A (1977) Trade in the second and third millenia BC between Maghreb and Iberia. In: Markotic V (ed) Ancient Europe and the Mediterranean: studies presented in honour of Hugh Hencken. Aris \& Phillips, Warminster, pp 89-104

Heimann RB, Maggetti M (2014) Ancient and historical ceramics: materials, technology, art and culinary traditions. Schweizerbart Science, Stuttgart

Hein A, Müller NS, Day PM, Kilikoglou V (2008) Thermal conductivity of archaeological ceramics: the effect of inclusions, porosity and firing temperature. Thermochim Acta 480:35-42. https://doi.org/ 10.1016/j.tca.2008.09.012

Hunt-Ortiz MA, Consuegra-Rodríguez S, Díaz del Río-Español P, et al (2011) Neolithic and Chalcolithic - Vi to III millenia BC - use of cinnabar $(\mathrm{HgS})$ in the Iberian Península: analytical identification and lead isotope data for an early mineral exploitation of the Almadén (Ciudad Real, Spain) minning district. In: Ortiz JE, Puche O, Rábano I, Mazadiego LF (eds) History of research in mineral resources

Inácio N, Calvo FN, Nieto JM et al (2012) Producción y distribución de cerámica en el suroeste de la Península ibérica. Datos Preliminares del análisis arqueométrico aplicado al yacimiento de la junta (Puebla de guzmán, huelva). Cuad Prehist Arqueol Univ Granada 20:329-354

Inácio N, Nocete F, Bayona MR, Nieto JM (2013) Propuesta de un modelo económico para la alfarería del III milenio a.n.e. en el Suroeste peninsular desde el análisis arqueométrico del registro ceramológico de Cabezo Juré (Alosno, Huelva). In: Jiménez Ávila J, Bustamante Álvarez M, García Cabezas M (eds) Encuentro de Arqueología del Suroeste Peninsular VI VI. Ayuntamiento de Villafranca de los Barros, Villafranca de los Barros, pp 575-594
Inácio N, Nocete F, Nieto JM et al (2011) From raw materials to utilisation. Ceramics associated with the metalurgical activity at Valenciana de la Concepción (Seville, Spain): technological choices and social implications. In: Scarcella S (ed) Archaeological ceramics: a review of current research. Archaeopress, Oxford, pp 73-79

Livingstone Smith A (2001) Bonfire II: the return of pottery firing temperatures. J Archaeol Sci 28:991-1003. https://doi.org/10.1006/jasc. 2001.0713

Kampschuur W, García Monzón G (1975) Report of geological map sheet n. 1031 (Sorbas). Mapa geológico de España E. 1:50.000. IGME, Madrid

Kampschuur W, García Monzón G, Verburt V (1975) Geological map sheet n. 1031 (Sorbas). Mapa geológico de España E. 1:50.000. IGME, Madrid

Kohring S, Odriozola CP, Hurtado VM (2007) Materialising "complex" social relationships: technology, production and consumption in a Copper Age community. In: Kohring S, Wynne-Jones S (eds) Socialising complexity: structure, interaction and power in archaeological discourse. Oxbow Books, Oxford, pp 100-117

Leisner GK, Leisner V (1943) Die Megalithgräber der Iberischen Halbinsel. Wde Gruyter, Berlin

Longacre WA (1999) Standardization and specialization: what's the link? In: Skibo JM, Feinman GM (eds) Pottery and people: a dynamic interaction. University of Utah Press, Salt Lake City, pp 44-58

Lull V (1983) La cultura de El Argar: (un modelo para el estudio de las formaciones economico-sociales prehistoricas). Akal, Madrid

Lull V, Micó R, Rihuete Herrada C, Risch R (2010) Metal and social relations of production in the 3rd and 2nd millennia BCE in the southeast of the Iberian Peninsula. Trab Prehist 67:323-347. https://doi.org/10.3989/tp.2010.10042

Maggetti M, Neururer C, Ramseyer D (2011) Temperature evolution inside a pot during experimental surface (bonfire) firing. Appl Clay Sci 53:500-508. https://doi.org/10.1016/j.clay.2010.09.013

Maniatis Y, Tite MS (1978) Ceramic technology in the Aegean world during the Bronce Age. In: Doumas C (ed) Thera and the Aegean world. Papers presented at the second international scientific congress, Santorini, Greece, August 1978. London, pp 483-492

Maniatis Y, Tite MS (1981) Technological examination of NeolithicBronze Age pottery from central and Southeast Europe and from the near east. J Archaeol Sci 8:59-76. https://doi.org/10.1016/03054403(81)90012-1

Martín Socas D, Camalich Massieu MD (1982) La "cerámica simbólica" y su problemática (aproximación a través de los materiales de la colección L. Siret). Cuad Prehist Arqueol Univ Granada 7:267-306

Martín-Socas D, Camalich Massieu MD, Herrero JLC, Rodríguez-Santos FJ (2017) The beginning of the Neolithic in Andalusia. Quat Int. https://doi.org/10.1016/j.quaint.2017.06.057

Martinón-Torres M, Rehren T (2014) Technical Ceramics. In: Roberts BW, Thornton CP (eds) Archaeometallurgy in Global Perspective. Springer New York, New York, NY, pp 107-131

Mathers C (1984) Beyond the grave: the context and wider implications of mortuary practices in south-east Spain. In: Blagg TFC, Jones RFJ, Keay SJ (eds) Papers in Iberian archaeology. B.A.R, Oxford

Matthew AJ, Woods AJ, Oliver C (1997) Spots before the eyes: new comparison charts for visual percentage estimation in archaological material. In: Recent developments in ceramic petrology. British Museum, Londres

Molina F, Cámara J, Capel J et al (2004) Los Millares y la periodización de la Prehistoria Reciente del Sudeste. In: II-III Simposio de Prehistoria Cueva de Nerja. Fundación Cueva de Nerja, Nerja, pp $142-158$

Molina F, Cámara JA (eds) (2005) Guía del enclave arqueológico Los Millares. Junta de Andalucia, Sevilla

Montero Ruiz I (1993) Bronze Age metallurgy in southeast Spain. Antiquity 67:46-57. https://doi.org/10.1017/S0003598X0004504X 
Montero Ruiz I, Murillo-Barroso M (2014) Difusión o innovación tecnológica: los inicios de la metalurgia en la Península Ibérica. In: García Alfonso E (ed) Movilidad Contacto y Cambio. Actas del II Congreso de Prehistoria de Andalucía. Junta de Andalucía, e-book, Spain

Montero Ruiz I, Murillo-Barroso M (2016) Los inicios de la metalurgia y el valor social del metal. Menga 7:15-29

Müller NS, Kilikoglou V, Day PM, Vekinis G (2010) The influence of temper shape on the mechanical properties of archaeological ceramics. J Eur Ceram Soc 30:2457-2465. https://doi.org/10.1016/j. jeurceramsoc.2010.04.039

Müller R, Rehren T, Rovira S (2006) The question of early copper production at Almizaraque, SE Spain. 34th Int Syposium Archaeom Zaragoza 2004:209-219

Murillo-Barroso M, Martinón-Torres M (2012) Amber sources and trade in the prehistory of the Iberian Peninsula. Eur J Archaeol 15:187216. https://doi.org/10.1179/1461957112Y.0000000009

Murillo-Barroso M, Martinón-Torres M, Camalich Massieu MD et al (2017) Early metallurgy in SE Iberia. The workshop of Las Pilas (Mojácar, Almería, Spain). Archaeol Anthropol Sci 9:1539-1569. https://doi.org/10.1007/s12520-016-0451-8

Murillo-Barroso M, Montero-Ruiz I (2012) Copper ornaments in the Iberian Chalcolithic: technology versus social demand. J Mediterr Archaeol 25:53-73

Nocete F, Queipo G, Sáez R, Nieto JM, Inácio N, Bayona MR, Peramo A, Vargas JM, Cruz-Auñón R, Gil-Ibarguchi JI, Santos JF (2008) The smelting quarter of Valencina de la Concepción (Seville, Spain): the specialised copper industry in a political centre of the Guadalquivir Valley during the third millennium BC (2750-2500 BC). J Archaeol Sci 35:717-732. https://doi.org/10.1016/j.jas.2007.05.019

Pellicer Catalán M (1995) Las culturas del neolítico-calcolítico en Andalucía Oriental. Espac Tiempo Forma Ser Prehist Arqueol 81-134

Perucchetti L, Bray P, Dolfini A, Pollard AM (2015) Physical barriers, cultural connections: prehistoric metallurgy across the alpine region. Eur J Archaeol 18:599-632. https://doi.org/10.1179/1461957115Y. 0000000001

Radivojević M, Rehren T (2016) Paint it black: the rise of metallurgy in the Balkans. J Archaeol Method Theory 23:200-237. https://doi. org/10.1007/s10816-014-9238-3

Ramos Millán A (1981) Interpretaciones secuenciales y culturales de la Edad del Cobre en la zona meridional de la Península Ibérica. La alternativa del materialismo cultural. Cuad Prehist Arqueol Univ Granada 6:203-256

Renfrew C (1967) Colonialism and megalithismus. Antiquity 41:276288. https://doi.org/10.1017/S0003598X00033512
Risch R (2008) Recursos naturales y sistemas de producción en el sudeste de la Península Ibérica entre 3000 y 1000 ANE. Universitat Autònoma de Barcelona, Barcelona

Risch R, Martínez Fernández F, Gibaja Bao JF (2002) Recursos naturales, medios de producción y explotación social: un análisis económico de la industria lítica de Fuente Álamo, (Almería), 2250-1400 antes de nuestra era. Verlag Philipp Von Zabern, Mainz am Rhein

Roberts B (2008) Migration, craft expertise and metallurgy. Archaeol Rev Camb 23:27-45

Roberts BW (2014) Production networks and consumer choice in the earliest metal of Western Europe. In: Roberts BW, Thornton CP (eds) Archaeometallurgy in global perspective: methods and syntheses. Springer, New York, pp 423-446

Rovira S (2002) Early slags and smelting by-products of copper metallurgy in Spain. In: Bartelheim E, Krause R (eds) Die Anfänge der Metallurgie in der Alten Welt/The beginnings of metallurgy in the Old World. Marie Leidorf GmbH, Rahden/ Westfalia, pp 83-98

Rovira S (2005) Metalurgia de crisol: la obtención de cobre en la prehistoria de la Península Ibérica. Re Met Madr Rev Soc Esp Para Def Patrim Geológico Min:87-94

Rovira S, Ambert P (2002) Les céramiques à réduire le minerai de cuivre: une technique métallurgique utilisée en Ibérie, son extension en France méridionale. Bull Société Préhistorique Fr 99:105-126. https://doi.org/10.3406/bspf.2002.12609

Rovira S, Renzi M (2017) Early technologies for metal production in the Iberian Peninsula. Mater Manuf Process 32:756-764. https://doi. org/10.1080/10426914.2017.1291946

Ruiz-Taboada A, Montero-Ruiz I (1999a) Ocupaciones neolíticas en Cerro Virtud: estratigrafía y dataciones. SAGVNTVM Extra 2: 207-211

Ruiz-Taboada A, Montero-Ruiz I (1999b) The oldest metallurgy in western Europe. Antiquity 73:897-903. https://doi.org/10.1017/ S0003598X00065650

Salanova L (2012) Productions domestiques, productions spécialisées... et le reste? Les différents types de productions céramiques néolithiques. Bull Société Préhistorique Fr 109:221-229. https:// doi.org/10.3406/bspf.2012.14104

Thomas J (2009) Approaching specialisation: craft production in Late Neolithic/Copper Age Iberia

Whitbread IK (2016) Fabric description of archaeological ceramics. In: Hunt AMW (ed) The Oxford handbook of archaeological ceramic analysis. Oxford University Press, New York

Whitbread IK (1995) Greek transport amphorae: a petrological and archaeological study. British School at Athens, Athens

Zachos K (2007) The Neolithic background: a reassessment. In: Day PM, RCP D (eds) Metallurgy in the Early Bronze Age Aegean. Oxbow Books; David Brown Book, Oxford, pp 167-206 